\title{
The development and experimental validation of a reduced ternary kinetic mechanism for the auto-ignition at HCCI conditions, proposing a global reaction path for ternary gasoline surrogates
}

\author{
Hatim Machrafi*, Simeon Cavadias, Jacques Amouroux \\ UPMC Université Paris 06, LGPPTS, Ecole Nationale Supérieure de Chimie de Paris, 11, rue de Pierre et Marie \\ Curie, 75005 Paris, France \\ Tel.: +331442767 18; Fax: +33143265813
}

\begin{abstract}
To acquire a high amount of information of the behaviour of the Homogeneous Charge Compression Ignition (HCCI) auto-ignition process, a reduced surrogate mechanism has been composed out of reduced n-heptane, iso-octane and toluene mechanisms, containing 62 reactions and 49 species. This mechanism has been validated numerically in a $0 \mathrm{D}$ HCCI engine code against more detailed mechanisms (inlet temperature varying from 290 to $500 \mathrm{~K}$, the equivalence ratio from 0.2 to 0.7 and the compression ratio from 8 to 18) and experimentally against experimental shock tube and rapid compression machine data from the literature at pressures between 9 and 55 bar and temperatures between 700 and $1400 \mathrm{~K}$ for several fuels: the pure compounds n-heptane, iso-octane and toluene as well as binary and ternary mixtures of these compounds. For this validation, stoichiometric mixtures and mixtures with an equivalence ratio of 0.5 are used. The experimental validation is extended by comparing the surrogate mechanism to experimental data from an HCCI engine. A global reaction pathway is proposed for the auto-ignition of a surrogate gasoline, using the surrogate mechanism, in order to show the interactions that the three compounds can have with one another during the auto-ignition of a ternary mixture.
\end{abstract}

*Corresponding author.

E-mail address: hatim-machrafi@enscp.fr 
Keywords: Model reduction, HCCI auto-ignition, Combustion, Kinetics, Numerical validation, Experimental validation, ternary gasoline surrogate

\section{Introduction}

In the daily life, internal combustion engines are used very often, mainly for transport purposes such as driving cars. This results into large-scale consumption, depletion of limited fossil-fuel reserves and the production of exhaust gases that harm both the environment and our health. On the other hand, they provide also advantages, such as mobility, that are linked to the widespread availability of passenger cars. Regardless of one's perspective, it seems correct to expect that the number of vehicles (with an internal combustion, IC, engine) will rise in the future, especially when considering the fast economic development around the world. Furthermore, legislation restricts the amount of emissions emitted by the engines. Respecting the Euro IV emission norms in 2005, possibilities as the catalytic oxidation, the $\mathrm{NO}_{\mathrm{x}}$ traps and the particulate traps can be used, in other words: post-treatment. However, for the future Euro emission norms, the restrictions are more severe and another solution has to be found. The world-wide fuel consumption and exhaust emissions can realistically be reduced if an alternative for the IC engine is developed with characteristics that are significantly better than those of present engines. Concerning the emission reduction during the combustion process, Homogeneous Charge Compression Ignition (HCCI) promises to be a good solution to respect these future Euro norms. HCCI can be defined as a premixed, lean burn combustion process, preceded by a homogeneous air/fuel port-injection. The HCCI engine generally runs on a lean, diluted mixture of fuel, air and combustion products, which is not ignited by a spark but by compression auto-ignition instead. Using a lean burn combustion process at lower temperatures and a premixed air-fuel mixture, the HCCI combustion allows for a higher thermal efficiency than spark ignition engines, less particulate-matter emissions 
than diesel engines and generally less $\mathrm{NO}_{\mathrm{x}}$ emissions. Whereas diesel combustion is mainly controlled by turbulence during flame diffusion and gasoline combustion with a flame front propagation, the auto-ignition phenomenon in an HCCI engine is mainly controlled by chemical kinetics and its combustion initiation is rather complicated to control. Much research [1-6] is performed regarding kinetic mechanisms, the auto-ignition for many compounds and HCCI combustion. A great part of the HCCI investigations [7-9] use the socalled Primary Reference Fuels (PRF) such as iso-octane and n-heptane. [To account for aromatics in gasoline and especially diesel, mostly toluene is added for this purpose [10-14]. Numerical work regarding PRF's and toluene can be found, for instance, in $[\mathbf{1 5 , 1 6 ]}$. Therefore these three fuels should be investigated. The application of parametrical analysis on autoignition requires kinetic models of low dimensionality. Also, the behaviour of multidimensional models of ignition in a combustion chamber may be explored relatively more easily with a reduced mechanism when a detailed numerical approach to the fluid dynamics is also included as in CFD calculations. The purpose of reduced modelling work is that many calculations can be made within a short period of computing time. Though much important modelling work on the auto-ignition of PRF's $[\mathbf{1 7 , 1 8}]$ and other (pure/binary) compounds [19-21] has been done, not much modelling and experimental work on ternary mixtures that represent gasoline can be found in the literature $[\mathbf{2 2 , 2 3 , 2 4 ]}$. This calls for the need of such mechanisms that can contribute to the understanding of the auto-ignition of gasoline in HCCI engines. Therefore, the aim of this paper is to compose a strongly reduced "surrogate mechanism" for mixtures of n-heptane, iso-octane and toluene for HCCI auto-ignition applications. Knowing that diesel surrogates can be represented by mixtures of n-heptane and toluene, the purpose of this mechanism can be extended to the use for diesel fuel applications as well. The purpose is also to validate this mechanism numerically against detailed 
mechanisms in an engine like environment and experimentally against experimental data at a constant volume environment.

It is said previously that, contrary to conventional gasoline or diesel combustion, the HCCI combustion is mainly controlled by chemical reactions. The fuels considered in this work are n-heptane, iso-octane and toluene. The chemistry of the reaction paths of n-heptane, isooctane and toluene are well known and discussed in the literature. For the kinetics of nheptane, iso-octane and toluene combustion, one may be referred to [25-31].

\section{Methodology of obtaining a numerically validated reduced surrogate mechanism}

\subsection{Numerical outline of this work}

Some criteria should be defined, to which the reduced mechanisms should adhere, for the reduced mechanisms to be validated at a certain parameter range (inlet temperature, equivalence ratio, compression ratio and fuel composition). At each criterion a certain accuracy range is indicated. The accuracy can be divided into two accuracy levels. The first level is where the error of the criterion, with respect to the detailed mechanisms, is minimal and the criterion gives a good agreement between the reduced mechanisms and the detailed one. The second level is where the error is too large for the criterion to be reliable, but enough to give a correct trend. These criteria should represent the auto-ignition process characteristics. Such a process can be represented by several criteria, like the pressure, the heat release, the formation and consumption of intermediate species, the work delivered on an engine piston, the ignition delays, the exhaust species, the efficiency of a combustion cycle, to mention a few. Since in this paper the kinetic mechanism is ought to predict correctly the overall kinetic and thermodynamic characteristics of the auto-ignition process, only some of the abovementioned criteria would be sufficient. To assess the overall process in terms of a 
global and apparent outcome of the auto-ignition, the pressure in the cylinder becomes an important entity. It is this pressure that gives the power to an engine. The pressure is very sensitive to the input parameters and operating conditions. This includes the type of fuel, the engine configuration, the compression ratio, the equivalence ratio, the operating temperature, engine efficiency, heat loss and engine cooling. In other words, to obtain the same pressure profile, it is necessary that these parameters do not change much. Therefore, comparing a simulated pressure profile to an experimental one indicates whether the mechanism is capable to predict the sensitiveness of the experimental pressure and is thus a powerful criterion. The power in an engine, however, is also a function of the phasing of the combustion. This can be represented by the heat release. The heat release is calculated from the First Law of Thermodynamics, by means of an energy balance leading to the following equation:

$\frac{d Q_{\text {release }}}{d \theta}=\frac{d Q_{\text {wall }}}{d \theta}+\frac{\gamma}{\gamma-1} P \frac{d V}{d \theta}+\frac{1}{\gamma-1} V \frac{d P}{d \theta}$

In the case of a numerical validation study, the calculation of the heat loss to the wall is not necessary and can be discarded. The heat release profile can give information about when the combustion takes place and at what moment power is delivered. The heat release represents also the chemical energy that is released and therefore makes the link between the engine's power and the chemical reactions that cause this energy. Since chemistry plays an important role in the HCCI combustion mode and an engine is involved, this criterion is particularly interesting. These two criteria can summarize the global thermodynamic or energetic characteristics of the auto-ignition process. The assessment of the kinetic characteristics can be done by looking to the ignition delays. From the literature [25-31], it can be extracted that during an HCCI auto-ignition process, a cool flame and final ignition can be defined. In this section, the cool flame delay is defined as the number of Crank Angle Degrees (CAD) from Bottom Dead Center at the beginning of the compression stroke (BDC) until the first maximum of the heat release. The final ignition delay is defined as the number of CAD from 
$\mathrm{BDC}$ until the second maximum of the heat release. These ignition delays represent the moment of increased kinetic activity and can represent on their turn the chemical reaction pathways in the mechanism. Furthermore, for the engine to function properly, the timing of the ignition delay is crucial. As such, it can be used as an important criterion for this study. Intermediate species play an important role as well. They are directly or indirectly linked to the ignition delays. For instance, one of the species that play an important role during the cool flame is the species formaldehyde $\left(\mathrm{CH}_{2} \mathrm{O}\right)$ and during the final ignition the radical $\mathrm{OH}$ is one of the important species. A considerable formation of formaldehyde is observed during the cool flame, while the $\mathrm{OH}$ radical is the main species that consumes the fuel during the final ignition $[\mathbf{2 7 , 2 8 , 3 0 ]}$. Therefore, the evolutions of these species are taken as a criterion. To be able to control the ignition delay, it is very important that the error should be very small. The validation during the reduction is done numerically. The error range for the ignition delays should be as good as nihil. However, the moment of an ignition delay has been defined as the maximum of the heat release. The determination of this maximum is subject to discussion, since the formation of the species that are responsible for this heat release does not take place at exactly the same time. This allows for a certain error range, being in the order of 0.5 to 1 CAD, depending on the initial conditions. Since for control purposes an error of higher than 1 CAD becomes less interesting, the error of the ignition delays is therefore taken to be maximally $1 \mathrm{CAD}$ in the case of a first level accuracy. The error of the other criteria are taken in the same perspective, accepting an error of 1 bar for the maximum pressure, $10 \% \mathrm{~J} / \mathrm{CAD}$ for the maximum heat release and $10 \mathrm{vol} \%$ for the species. As far as it concerns the second level of accuracy, an error of higher than $3 \mathrm{CAD}$ can no longer allow for a qualitative comparison, since in some cases the duration of a cool flame is of an order of 3 to 4 CAD. The other criteria values are judged in the same light, leading to an error of 3 bar in the maximum pressure, $30 \% \mathrm{~J} / \mathrm{CAD}$ for the maximum heat release and $30 \mathrm{vol} \%$ for the species. 
The next subsection presents the reduction, development and composition of the ternary mixture mechanism as well as its numerical validation in a $0 \mathrm{D} \mathrm{HCCI}$ engine code as is explained in this subsection.

\subsection{Reduction, composition and validation of the surrogate mechanism}

This section describes the reduction methodology of the iso-octane mechanism and the nheptane mechanism, developed and provided by [15], containing 412 reactions and 84 species and 290 reactions and 57 species, respectively, as well as the reduction methodology of the toluene mechanism, developed and provided by [16], containing 617 reactions and 88 species. The iso-octane and n-heptane mechanisms have previously been validated experimentally in a shock tube between 600 and $1000 \mathrm{~K}$ and between 15 and 35 bar and subsequently applied to HCCI modeling by the former authors. The toluene mechanism has also been validated in a shock tube at temperatures around $1000 \mathrm{~K}$ and equivalence ratios between 0.379 and 0.65 , at atmospheric pressure by the latter authors. Also a composition of these three reduced mechanisms for gasoline surrogate mixtures of n-heptane, iso-octane and toluene will be discussed in this section. Two equivalence ratios are used during the reduction, 0.4 and 1.0, in order to extend the usability of the mechanism.

The reduction is performed in a methodological way, using methods that are presented in the literature and adapting these at low inlet temperatures and low equivalence ratios respecting HCCI conditions. These methods are explained in this subsection. Firstly, the species were tested for their relative life times. According to [32], fast reactions, occurring in for instance a stationary state or partial equilibrium, have short chemical time scales corresponding to the range $10^{-6}-10^{-7} \mathrm{~s}$. If the life time is smaller than $10^{-7} \mathrm{~s}$, this species is considered to have little influence on the heat release and is thus eliminated. This step goes along with the second step, presenting the quasi-steady-state assumption and partial equilibrium assumption. By 
introducing the quasi-steady-state assumption (QSSA) $[33,35,36]$ and the partial equilibrium assumption (PE) $[\mathbf{3 3 , 3 5 , 3 6 ]}$, the mechanisms were reduced thus furthermore. This approach is well known and is proven to be successful for the construction of reduced chemical kinetic schemes for the combustion of several hydrocarbons [33-37]. At this moment the mechanism is reduced considerably. However, the objective is to have a strongly reduced mechanism that accounts only for HCCI engine conditions, presenting the third step. This method relies primarily on the philosophy of the global reaction schemes of the individual compounds nheptane, iso-octane and toluene, as is presented in the literature [24-31]. On preserving the overall global reaction paths, for low-inlet-temperature HCCI hydrocarbon chemistry, the mechanisms are further reduced, eliminating the species and reactions that govern the high inlet-temperature regions at low pressures (such as the decomposition of the fuel into alkyl radicals). This does not imply the high temperature reactions at high pressures, since, when considering the case of an engine, these take place at the final ignition and not at the initial conditions. Thus, only the most important reactions that govern the temperature and pressure profiles at low-inlet-temperature chemistry are kept (the reactions that prescribe, for instance, $\mathrm{H}$-abstraction, peroxide formation, peroxide isomerization and decomposition, formation of formaldehyde, $\mathrm{H}_{2} \mathrm{O}_{2}, \mathrm{OH}, \mathrm{CO}, \mathrm{CO}_{2}, \mathrm{H}_{2} \mathrm{O}$ describing well the cool flame and the NTC-region). The n-heptane and iso-octane mechanisms provided by Chalmers [15] were thus reduced to respectively 21 reactions / 27 species and 29 reactions / 27 species and are presented in respectively table 1 and table 2 . Subsequently a detailed toluene mechanism [16] was reduced for the purposes of this paper to 18 reactions and 19 species, using the same reduction methodology. This mechanism is presented in table 3 . The fourth step consists of merging the individual reduced mechanisms of $n$-heptane, iso-octane and toluene into a surrogate mechanism for gasoline and diesel applications. The surrogate mechanism is presented in table 4, containing 62 reactions and 49 species. This step is accompanied by adding the 
individual reduced mechanisms to one another and eliminating reactions of which the reaction rate and reaction heat formation are lower. This also concerns reactions that are present in the individual mechanisms that are the same. For instance, reactions 11 and 16 in respectively tables 1 and 2 are the same. In table 4, only reaction 11 is kept, since the heat formation and ethene production of reaction 16 appeared to be insignificant with respect to those of reaction 11. The threshold that is taken is that the ratio of respectively the reaction heat release and ethene production of reaction 11 to that of reaction 16 should be more than a 10 . This value is thought of being reasonable, for a higher ratio would be unnecessary, regarding the numerical validation criteria, mentioned in the previous subsection. Looking to reactions 48 and 49 in table 4 , it can be seen that the reactions describing the formation of $\mathrm{CO}_{2}$, by $\mathrm{CO}+\mathrm{O}$, differ by a third body. This can be explained as these reactions have their importance depending on the temperature interval. A fuel that contains a majority of iso-octane does not need very high temperatures to auto-ignite. For such a fuel, it appeared from the mechanism that the heat release contribution and $\mathrm{CO}_{2}$ production by the reaction $\mathrm{CO}+\mathrm{O}+\mathrm{M}=\mathrm{CO}_{2}+\mathrm{M}$ made the contributions of the reaction $\mathrm{CO}+\mathrm{O}=\mathrm{CO}_{2}$ insignificant. On the other hand, a fuel containing a majority of toluene needs high temperatures to auto-ignite. In that case, the reaction $\mathrm{CO}+\mathrm{O}$ $+\mathrm{M}=\mathrm{CO}_{2}+\mathrm{M}$ appeared to be insignificant. The same is the case for the reactions 56 and 57 in table 4. Looking to reactions 61 and 62 in table 4, it can be seen that the reaction describing the decomposition of $\mathrm{H}_{2} \mathrm{O}_{2}$ into $\mathrm{OH}$ radicals is pressure dependent in reaction 62 contrary to reaction 61 . The latter reaction comes from the toluene mechanism. It appeared from reaction rate analysis of the mechanism in table 4 , that for pure toluene, the decomposition of $\mathrm{H}_{2} \mathrm{O}_{2}$ proceeded primarily by reaction 61 , while for pure $n$-heptane and iso-octane this proceeded by reaction 62. Eliminating any of the two reactions gave incorrect results. In order to be able to use the mechanism for various fuel compositions, both the reactions are kept. The fifth and last step consists of validating the obtained mechanism with respect to the individual detailed 
mechanisms at engine-like environments, comparing the pressure, the heat release, the ignition delays and the species $\mathrm{CH}_{2} \mathrm{O}$ and $\mathrm{OH}$. This also means that the surrogate mechanism should give the same results for n-heptane auto-ignition when it is compared to a detailed mechanism of $n$-heptane. The input parameters for the fuel will consist of $100 \mathrm{vol} \% \mathrm{n}$-heptane and 0 vol $\%$ of iso-octane and toluene. This shows whether the surrogate mechanism is able to reproduce the kinetics of n-heptane alone without that the reaction paths of iso-octane and toluene disturb the reaction path of n-heptane. The same is done for iso-octane and toluene. For these calculations, a 0D HCCI engine code is used, which is incorporated in the Chemkin IV [38] code, with a bore of $82.55 \mathrm{~mm}$, a stroke of $114.5 \mathrm{~mm}$ and an engine speed of 600 $\mathrm{rpm}$. The ratio of connecting rod to crank radius is 4.44 . The individual reduced n-heptane $(\mathrm{N}-$ hept21), iso-octane (Iso-oct29) and toluene (Toluene18) mechanisms are put in the comparison as well to measure the influence of the merging process. An extra comparison is made with the detailed n-heptane mechanism of LLNL, containing 2539 reactions and 561 species, provided by LLNL [25], in the case of $n$-heptane. This mechanism is validated experimentally in a plug flow reactor, a shock tube reactor, a rapid compression machine and a jet-stirred reactor at temperatures between 550 and $1700 \mathrm{~K}$, initial pressures from 1 to 42 atm, equivalence ratios from 0.3 to 1.5 and nitrogen-argon dilution between 70 and $99 \%$. For this comparison, different values of the inlet temperature, compression ratio, equivalence ratio and fuel composition are used. An example of the results of this numerical comparison is presented in figure 1 for $n$-heptane where the ignition delays, as calculated by the surrogate mechanism, are compared to the detailed mechanisms. Figure 1 shows that the detailed nheptane mechanism and their reduced counterpart as well as the surrogate mechanism show very good agreement with each other concerning the cool flame delays and the final ignition delays. To assess whether the numerical validation is accurate or not and at what range, the error of the ignition delays, predicted by the surrogate mechanism, with respect to the detailed 
mechanism is calculated. The results of the relative errors of the ignition delays are presented in figure 2. The relative errors are expressed as the ratio of the difference between the ignition delay of the reduced mechanism to that of the detailed mechanisms. The translucent areas in figure 2 represent the parameter ranges, where the difference in the final ignition is higher than 1 CAD. Figure 2 shows that the surrogate mechanism is reliable with respect to the final ignition delay for all the three fuels that are discussed and this holds for the majority of the ranges. This is found at compression ratios of 8 and 18 , equivalence ratios of 0.2 and 0.7 , inlet temperatures of $290 \mathrm{~K}$ and $500 \mathrm{~K}$.

Figure 3 shows an example of the numerical validation of the mechanism with respect to the cylinder pressure and the heat release, comparing the surrogate mechanism with its detailed source mechanism and that of LLNL, for the fuel n-heptane. The Chalmers mechanism and the surrogate mechanism do not show much difference for the CAD concerning the pressure and the heat release values $(<1 \mathrm{CAD})$. It seems that not only the ignition delay, but also the energetic content of the detailed mechanism is quite well represented by the reduced surrogate mechanism. Concerning the numerical validation with respect to intermediate species, figures 4 and 5 show some examples concerning the species $\mathrm{CH}_{2} \mathrm{O}$ and $\mathrm{OH}$. Again is observed that the prediction of the surrogate mechanism for the $\mathrm{CH}_{2} \mathrm{O}$ concentration profile is between that of the LLNL mechanism and the Chalmers mechanism. Apparently, the LLNL mechanism predicts a cool flame intensity which is higher than the other two mechanisms, while that of the surrogate is in between. For the comparison of the $\mathrm{OH}$ concentration, the fuels iso-octane and toluene are used, to broaden the comparison with respect to the type of fuel. These are presented in figure 5. It can be seen that the comparison of the $\mathrm{OH}$ concentration between the surrogate mechanism and their respective detailed mechanisms is largely within the first level of accuracy for both iso-octane and toluene at different conditions. Generally, it has appeared 
that the prediction of the reactivity and the energy content of the surrogate mechanism are between that of two validated detailed mechanisms. This points out that the numerical validation of the surrogate mechanism is anyway between already experimentally validated mechanisms.

Table 5 presents the domain of validity of the Surrogate mechanism with respect to the detailed mechanisms to which it is compared, showing that the surrogate mechanism is validated numerically within the majority of the investigated ranges. This validation concerns not only the pressure maximum, the heat release maximum, the cool flame delay and the final ignition delay, but also the profile of some important intermediate and final products.

The mechanism should be validated experimentally before it can be used for HCCI combustion applications. For this, the mechanism should be compared to experimental values at a relatively large range of temperatures and pressures in a constant volume environment. This validation is presented in the next section.

\section{Experimental validation of the surrogate mechanism}

Having obtained a reduced, numerically validated surrogate mechanism (Surrogate), this mechanism should be validated experimentally against experimental data in constant volume environments. In this experimental comparison, experimental data of ignition delays are issued from the literature and the ignition delays are calculated by the surrogate mechanism at the same operating conditions for stoichiometric fuel/air mixtures unless otherwise stated. For the individual fuels, n-heptane, iso-octane and toluene, the results of the detailed mechanisms are added in the same figures. The ignition delays that are issued from the surrogate mechanism are calculated by taking the time needed for the derivative of the pressure to attain a maximum. This choice gave the best fits with the experimental values. Nonetheless, if 
another choice would be made, like for instance the moment of maximum pressure or $90 \%$ consumption of the fuel, the value would not change much and the trends would be the same.

Figure 6 presents the comparison of the surrogate mechanism and the Chalmers mechanism with the experimental results issued from shock tube experiments performed at 10 bar with an equivalence ratio of 1.0 [15] and at 40 bar with an equivalence ratio of 0.5 [39] for iso-octane. In the shock tube the reacting gas at low pressure/temperature and a gas at high pressure are separated by a diaphragm. When the diaphragm is caused to burst, this produces a shock wave that travels down the low pressure section of the tube. The temperature and pressure of the reacting gas increases then, creating the conditions necessary for auto-ignition to occur. The test section is equipped at different positions with acceleration-compensated piezoelectric pressure transducers and opposite quartz windows for the registration of $\mathrm{CH}$-radical band emission at $431 \mathrm{~nm}$. Figure 6 shows that at lower temperatures $(1000 / \mathrm{T}>1.1)$, the ignition delays calculated by the surrogate mechanism agree well with those of the Chalmers mechanism. This corresponds at temperatures below $900 \mathrm{~K}$. As figure 6 shows, the Negative Temperature Coefficient region (NTC) is represented by both the mechanisms in a similar way. Looking at the temperatures above $900 \mathrm{~K}$, it seems that the surrogate mechanism predicts lower ignition delays. The experiments performed by [15] and [39] show a good agreement with both the mechanisms at a temperature of $690 \mathrm{~K}$. At temperatures above 1000 $\mathrm{K}$, the same good agreement is found between the experiments and the surrogate mechanism. In between these temperatures, it can be seen that a discrepancy exists between the experimental data provided by [15] and the surrogate mechanism, which are not due to the reduction methodology since the detailed mechanism differs even somewhat more. The trend, though, is satisfactorily predicted by the surrogate mechanism, which makes the overall trend, proposed by the surrogate mechanism, rather acceptable over the whole range of temperature 
for the fuel iso-octane for a pressure of 10 bar (equivalence ratio $=1.0$ ) and 40 bar (equivalence ratio $=0.5$ )

Figure 7 shows the same results as figure 6, but for the fuel PRF60 at 40 bar, using other experimental data from a shock tube [40]. In figure 7 the Chalmers mechanism for PRF fuels (the n-heptane and iso-octane mechanisms were merged together for this work) is compared to the surrogate mechanism showing a good agreement, except around the NTC region, where the Chalmers mechanism predicts higher ignition delays. The trend, however, corresponds well with that of the surrogate mechanism. The experimental values, presented by Curran et al. [40], show a satisfactory agreement with the surrogate mechanism for the fuel PRF60 at 40 bar over the whole range of presented temperatures. These results show as well that merging detailed mechanisms can give more difficulties than merging reduced mechanisms, since the interactions between the reactions are more complex, leaving place for more error.

Figure 8 shows the same results as figure 7, but for n-heptane at 42 bar, using experimental data from a shock tube [29]. Figure 8 shows that for the fuel n-heptane at 42 bar, the ignition delays that are predicted by the surrogate mechanism show the same trend as those predicted by the Chalmers mechanism. The experiments performed by Ranzi et al. [29] show a good agreement with the surrogate mechanism at the whole temperature range and give ignition delay values between those of the surrogate mechanism and the Chalmers mechanism.

Figure 9 shows a comparison of the surrogate mechanism and the Djurisic mechanism with experimental data from a rapid compression machine [41] and a shock tube [42] for toluene at 9 bar for an equivalence ratio of 1.0. In the rapid compression machine the reacting gas is compressed adiabatically rapidly (in the range of $10^{-2} \mathrm{~s}$ ) in a cylinder by one single stroke, causing the temperature and pressure to increase suddenly creating the proper conditions for auto-ignition. The ignition delay is obtained from the moment of pressure rise, which is measured in the cylinder. Figure 9 shows the comparison of the detailed toluene mechanism 
of Djurisic and the surrogate mechanism for toluene at 9 bar. A good agreement is found both qualitatively and quantitatively, with some discrepancy at temperatures higher than $1000 \mathrm{~K}$, which can be due to the elimination of the high temperature reactions of toluene leaving only the usual high temperature reactions of $\mathrm{H} / \mathrm{O}$ and $\mathrm{C}_{1}$ species. This seems to be quite enough to predict the auto-ignition of toluene. However, figure 9 seems to indicate that at temperatures higher than $1400 \mathrm{~K}$, the surrogate mechanism can no longer be used for toluene auto-ignition at 9 bar and the eliminated high temperature reactions of toluene will be necessary for a correct auto-ignition delay prediction. The experimental results of Bounaceur et al. [42] at 9.5 bar and an equivalence ratio of 1.0 seem to confirm this. For a temperature lower than $1400 \mathrm{~K}$ $(1000 / T>0.71)$, the experimental results are between the surrogate mechanism and the Djurisic mechanism. At temperatures higher than $1400 \mathrm{~K}$, the ignition delays from the surrogate mechanism seem to deviate considerably from the experimental values. At intermediate temperatures between 800 and $1000 \mathrm{~K}$, both the surrogate mechanism and the Djurisic mechanism agree well with the experimental values of Griffiths et al. [41] at 9 bar. Figure 10 shows the results for a fuel containing 35 vol $\%$ n-heptane and 65 vol $\%$ toluene at an equivalence ratio of 1.0. Having compared the surrogate mechanism in a satisfactory way with the detailed mechanisms of n-heptane, iso-octane and toluene, the surrogate mechanism is now compared only to the experimental values at respectively 10 and 30 bar, performed by Herzler et al. [43]. At both the pressures, the agreement is good. A small difference (about 30 $\mathrm{K}$ ) is observed for the temperature at which the NTC begins. It seems that at $10 \mathrm{bar}$, the experimental value shows an NTC beginning at $950 \mathrm{~K}$, while the surrogate mechanism show a starting temperature of $910 \mathrm{~K}$. At $30 \mathrm{bar}$, these values are respectively $830 \mathrm{~K}$ and $870 \mathrm{~K}$. Considering model reduction effects, these differences are too small in order to conclude from it any explanation, especially when the trends coincide well. 
Figure 11 shows a comparison of the surrogate mechanism with experimental results for a surrogate composed out of $17 \mathrm{vol} \% \mathrm{n}$-heptane, $63 \mathrm{vol} \%$ iso-octane and $20 \mathrm{vol} \%$ toluene at 20 and 55 bar in a shock tube [44]. Figure 11 also shows the same comparison for an equivalence ratio of 0.5 . It can be seen that for 20 bar, the experiments agree well with the surrogate mechanism, while for 55 bar this is only the case at temperatures higher than $1000 \mathrm{~K}$. For the values below $1000 \mathrm{~K}$, the trend is represented correctly by the surrogate mechanism, but the ignition delays are predicted to be higher by about $30 \%$ at the NTC. The reason for this could be that the reduction methodology implied an application to HCCI engine conditions. At temperatures below $1000 \mathrm{~K}$, the pressure is generally far below 55 bar. The same observations can be made for the results at an equivalence ratio of 0.5 . So the combination of these temperatures with the pressure of 55 bar is out of the purposes of the reduction methodology. Nonetheless, the error is not more than $30 \%$. So, considering the overall trend, this makes the prediction that is proposed by the surrogate mechanism rather acceptable over the whole range of temperature for this gasoline surrogate at 20 and 55 bar.

Figures 6 through 11 have shown that for different fuel compositions, pure n-heptane, pure iso-octane, pure toluene, a PRF60, a mixture of $35 \mathrm{vol} \% \mathrm{n}$-heptane and $65 \mathrm{vol} \%$ toluene and a ternary mixture of $17 \mathrm{vol} \% \mathrm{n}$-heptane, $63 \mathrm{vol} \%$ iso-octane and $20 \mathrm{vol} \%$ toluene, the overall trends were represented correctly by the surrogate mechanism with respect to the various experimental results from the literature at pressures varying from 9 to 55 bar and temperatures varying from 700 to $1400 \mathrm{~K}$ for equivalence ratios of 1.0 and 0.5 . At the majority of the cases the quantitative comparison was satisfactory as well. The mechanism would not be applicable if low temperatures would be associated to high pressures, such as a temperature of $700 \mathrm{~K}$ and a pressure of 55 bar. Comparisons of the surrogate mechanism with experimental data at 1 bar and temperatures higher than $1400 \mathrm{~K}$ have shown that this mechanism was not suitable for a combination of high temperatures and low pressures, such as $1500 \mathrm{~K}$ and 1 bar. This stems 
from the reduction methodology that stated that the mechanism should predict well the autoignition process during the combustion in an HCCI engine. During the combustion, the temperature and pressure increase simultaneously so that for this mechanism to be applicable, the pressure and temperature should not deviate too much from one another. The results of this work have shown that the combinations going from 40 bar / $700 \mathrm{~K}$ to 9 bar / $1400 \mathrm{~K}$ were acceptable. So it can be said that the surrogate mechanism has been validated experimentally over a wide range of pressures and temperatures adhering to engine operating conditions.

As a final comparison, an example is shown where previous experimental work is used to validate this surrogate mechanism [45] in an HCCI engine. For this purpose, a mixture of "11 vol\% n-heptane, 59 vol\% iso-octane and 30 vol $\%$ toluene" is used at an inlet temperature of $70{ }^{\circ} \mathrm{C}$, a compression ratio of 13.5 and an equivalence ratio of 0.462 . This mixture is used as a gasoline surrogate. The same "simulated" HCCI engine is used as is described in section 2.2. The experimental HCCI engine used in [45] has the same characteristics and geometry. The pressure and heat release are compared and the results are presented in figure 12 . Figure 12 shows that the pressure profiles and the heat release profiles in the HCCI engine agree well with each other. This shows that the validation procedure presented in this paper is acceptable.

\section{Proposition of the main reaction pathways of an n-heptane/iso-octane/toluene mixture}

Having validated the surrogate mechanism experimentally, the goal is to use a validated mechanism to propose a global reaction scheme for a gasoline surrogate, which consists out of the three components (n-heptane, iso-octane and toluene). This can be useful to show the interactions that these three compounds can have with one another during the auto-ignition of such a ternary mixture and it gives an insight of how this mechanism works. An example is presented in this subsection at an inlet temperature of $385 \mathrm{~K}$, an equivalence ratio of 0.6 and a 
compression ratio of 14 . The fuel used is the gasoline surrogate, mentioned earlier, containing 17 vol $\%$ n-heptane, 63 vol $\%$ iso-octane and 20 vol $\%$ toluene. The information acquired from the reduced mechanism makes it possible to construct a scheme that shows the main reaction path of linear and branched hydrocarbons that lead to the cool flame and finally the final ignition as well as the ignition of aromatics. To show the important reaction paths at each temperature interval, three representations are made for the same scheme, one during the cool flame, one during the NTC region and one during the final ignition. The thickness of the arrows represents the importance of that reaction with respect to the others at that temperature interval. This is determined by performing an analysis of the (heat) production rate of each reaction. The results are presented respectively in figures 13, 14 and 15 . In each of these schemes, the global positioning of the low-temperature interval is indicated with a dashed blue border, the intermediate-temperature interval with a dashed orange border and the hightemperature interval with a dashed red border. The initiation and consumption pathways are indicated by a black border. The double arrows represent the main species that are involved and deliver most of the heat release at the moment of the two ignition delays.

\section{Conclusions}

A surrogate mechanism, containing 62 reactions and 49 species, for ternary mixtures of nheptane, iso-octane and toluene has been developed from three different detailed mechanisms of the three aforementioned compounds. The surrogate mechanism compares well with the detailed mechanisms in an engine-like environment at different inlet temperatures, equivalence ratios and compression ratios for the three compounds. The domain of this numerical validation is between 310 and $500 \mathrm{~K}$ (inlet temperature), 0.2 and 0.7 (equivalence ratio) and $6-20$ (compression ratio), depending on the fuel. 
Experimental comparisons in a constant volume environment for several fuels (pure nheptane, pure iso-octane, pure toluene, a PRF60, a mixture of $35 \mathrm{vol} \% \mathrm{n}$-heptane and $65 \mathrm{vol} \%$ toluene and a ternary mixture of $17 \mathrm{vol} \% \mathrm{n}$-heptane, $63 \mathrm{vol} \%$ iso-octane and $20 \mathrm{vol} \%$ toluene) showed an overall good agreement of the trends predicted by the surrogate mechanism from pressures between 9 and 55 bar and temperatures between 700 and $1400 \mathrm{~K}$, provided that low temperatures, as $700 \mathrm{~K}$, are not combined with high pressures, as 55 bar. For this experimental validation, the equivalence ratios that were used are 1.0 and 0.5 . Quantitatively, the ignition delays calculated by the surrogate mechanism agreed well with the experiments in the majority of the cases. As an example, the surrogate mechanism is used for comparison against a gasoline surrogate auto-ignition in an HCCI engine. This comparison showed a satisfactory agreement.

It has appeared that the surrogate mechanism, containing a considerably small number of reactions and species, is able to simulate quite well, for the investigated conditions, different reaction paths in one single mechanism: linear alkanes (n-heptane), branched alkanes (isooctane) and aromatics (toluene). One example shows a global reaction path of the autoignition of a gasoline surrogate as is proposed by the surrogate mechanism. 


\section{References}

1 B. Johansson, P. Einewall, M. Christensen, Homogeneous Charge Compression Ignition (HCCI) Using Iso-octane, Ethanol and Natural Gas - A Comparison with Spark Ignition Operation (1997) SAE 972874.

2 H.J. Curran, P. Gaffuri, W.J. Pitz, C.K. Westbrook, A comprehensive modeling study of iso-octane oxidation, Combust. Flame, 129 (2002) 253-280.

3 S. Tanaka, F. Ayala, J.C. Keck, A reduced chemical kinetic model for HCCI combustion of primary reference fuels in a rapid compression machine, Combust. Flame, 133 (2003) 467-481.

4 S. Tanaka, F. Ayala, J.C. Keck, J.B. Heywood, Combust. Flame, Two-stage ignition in HCCI combustion and HCCI control by fuels and additives, 132 (2003) 219-239.

5 J.F. Griffiths, J.P. MacNamara, C.G.W. Sheppard, D.A. Turton, B.J. Whitaker, The relationship of knock during controlled autoignition to temperature inhomogeneities and fuel reactivity, Fuel, 81 (2002) 2219-2225.

6 H.T. Aichlmayr, D.B. Kittelson, M.R. Zachariah, Miniature free-piston homogeneous charge compression ignition engine-compressor concept-Part II: modeling HCCI combustion in small scales with detailed homogeneous gas phase chemical kinetics, Chem. Eng. Sc., 57 (2002) 4173-4186.

7 G. Kalghatgi, P. Risberg, H-E. Angstrom, A Method of Defining Ignition Quality of Fuels in HCCI Engines (2003) SAE 2003-01-1816.

8 J. Andrae, D. Johansson, P. Björnbom, P. Risberg, G. Kalghatgi, Co-oxidation in the auto-ignition of primary reference fuels and n-heptane/toluene blends, Combust. Flame 140 (2005) 267-286.

9 M. Sjöberg, J.E. Dec, Comparing late-cycle autoignition stability for single- and twostage ignition fuels in HCCI engines, Proc. Combust. Inst. 31 (2007) 2895-2902. 
10 I. Glassman, Combustion, Academic Press, San Diego, 1996.

11 P. Dagaut, G. Pengloan, A. Ristori, Oxidation, ignition and combustion of toluene: Experimental and detailed chemical kinetic modeling, Phys. Chem. Chem. Phys., 4 (2002) 1846-1854.

12 T. Faravelli, Kinetic Modeling of New Formulated Gasoline, Conference of Internal Combustion Engines, Capri, 1997.

13 J. Emdee, K. Brezinsky, I. Glassman, A Kinetic Model for the Oxidation of Toluene near 1200 K, J. Phys.Chem., 96 (1992) 2151-2161.

14 R. Lindstedt, L. Maurice, Detailed Kinetic Modelling of Toluene Combustion, Combust. Sci. Techn., 120 (1996) 119-167.

15 R. Ogink, V. Golovitchev, Generalised Skeletal Reaction Mechanism For Aliphatic Hydrocarbons (From Methane To Iso-octane) For CFD Engine Modelling. First Biennial Meeting of The Scandinavian-Nordic Section of the Combustion Institute, Göteborg, 2001, p. 151.

16 Z.M. Djurisic, A.V. Joshi, H. Wang, Detailed Kinetic Modeling of Benzene and Toluene Combustion. Second Joint Meeting of the U.S. Sections of the Combustion Institute, Oakland, 2001.

17 C. Westbrook, J. Warnatz, W. Pitz, A Detailed Chemical Kinetic Reaction Mechanism for the Oxidation of iso-Octane and n-Heptane over an Extended Temperature Range and its Application to Analysis of Engine Knock, Proc. Combust. Inst. 22 (1988) 893901.

18 G.M. Côme, V. Warth, P.A. Glaude, R. Fournet, F. Batin-Leclerc, G. Scacchi, Computer-Aided Design of Gas-Phase Oxidation Mechanisms-Application to the Modelling of n-Heptane and Iso-Octane Oxidation, Proc. Combust. Inst., 26 (1996) $755-762$. 
19 P.A. Glaude, V. Warth, R. Fournet, F. Batin-Leclerc, G. Scacchi, G.M. Côme, Modeling of the oxidation of n-octane and n-decane using an automatic generation of mechanisms, Int. J. Chem. Kin., 30 (1998) 949-959.

20 C. Gueret, M. Cathonnet, J.-C. Boettner, F. Gaillard, Experimental study and modeling of kerosene oxidation in a jet-stirred flow reactor, Proc. Combust. Inst., 23 (1990) 211 216.

21 M.U. Azuelta, P. Glarborg, K. Dam-Johansen, Experimental and kinetic modeling shidy of the oxidation of benzene, Int. J. Chem. Kin., 32 (2000) 498-522.

22 Z. Zhao, M. Chaos, A. Kazakov, P. Gokulakrishnan, M. Angioletti, F.L. Dryer, A PRF + toluene surrogate fuel model for simulating gasoline kinetics, Paper E26, 5th US Combustion Meeting, San Diego, CA, March 25-28, 2007.

23 J. Andrae, P. Björnbom, R.F. Cracknell, G.T. Kalghatgi, Autoignition of toluene reference fuels at high pressures modeled with detailed chemical kinetics, Combust. Flame 149 (2007) 2-24.

24 M. Fikri, J. Herzler, R. Starke, C. Schulz, P. Roth, G.T. Kalghatgi, Autoignition of gasoline surrogates mixtures at intermediate temperatures and high pressures, Combust. Flame, 152 (2008) 276-281.

25 H.J. Curran, P. Gaffuri, W.J. Pitz, C.K. Westbrook, A Comprehensive Modeling Study of n-Heptane Oxidation, Combust. Flame, 114 (1998) 149-177.

26 R.A. Cox, J.A.Cole, Chemical aspects of the autoignition of hydrocarbon---air mixtures, Combust. Flame, 60 (1985) 109-123.

27 S.W. Benson, The kinetics and thermochemistry of chemical oxidation with application to combustion and flames, Prog. Ener. Combust. Sc., 7 (1981) 125-134. 
28 N. Blin-Simiand, F. Jorand, K. Keller, M. Fiderer, K. Sahetchian, Ketohydroperoxides and ignition delay in internal combustion engines, Combust. Flame, 112 (1998) 278282.

29 E. Ranzi, P. Gaffuri, T. Faravelli, P. Dagaut, A wide-range modeling study of nheptane oxidation, Combust. Flame, 103 (1995) 91-106.

30 J.F. Griffiths, K.J. Hughes, R. Porter, The role and rate of hydrogen peroxide decomposition during hydrocarbon two-stage autoignition, Proc. Combust. Inst., 30 (2005) 1083-1091.

31 P. Dagaut, M. Reuillon, M. Cathonnet, High pressure oxidation of liquid fuels from low to high temperature. I: n-Heptane and iso-octane, Combust. Sc. Techn., 95 (1994) 233-260.

32 U. Maass, S.B. Pope, Simplifying chemical kinetics: Intrinsic low-dimensional manifolds in composition space, Combust. Flame, 88 (1992) 239-264.

33 J. Warnatz, U. Maas, R.W. Dibble, Combustion Physical and chemical fundamentals, modeling and simulation, experiments, pollutant formation, Springer-Verlag, New York, 2000.

34 T. Lu, Y. Ju, C.K. Law, Complex CSP for chemistry reduction and analysis, Combust. Flame, 126 (2001) 1445-1455.

35 I. Banerjee, M.G. Ierapetritou, Development of an adaptive chemistry model considering micromixing effects, Chem. Eng. Sc., 58 (2003) 4537-4555.

36 G. Dixon-Lewis, Computer modeling of combustion reactions in flowing systems with transport: combustion chemistry. J. William and C. Gardner, Springer-Verlag, New York, 1984. 
37 T. Lovas, D. Nilsson, F. Mauss, Automatic reduction procedure for chemical mechanisms applied to premixed methane-air flames, Proc. Combust. Inst., 28 (2000) 1809-1815.

38 R. J. Kee, M. E. Coltrin, P. Glarborg, Chemically Reacting Flow: Theory and Practice, John Wiley and Sons, Hoboken (2003).

39 K. Fieweger, R. Blumenthal, G. Adomeit, Self-ignition of S.I. engine model fuels: A shock tube investigation at high pressure, Combust. Flame, 109 (1997) 599-619.

40 H.J. Curran, W.J. Pitz, C.K. Westbrook, C.V. Callahan, F.L. Dryer, Oxidation of Automotive Primary Reference Fuels at Elevated Pressures, $27^{\text {th }}$ International Conference on Combustion Boulder, August 2-7, 1998.

41 J.F. Griffiths, P.A. Halford-Maw, D.J. Rose, Fundamental Features of Hydrocarbon Autoignition in a Rapid Compression Machine, Combust. Flame, 95 (1993) 291-306.

42 R. Bounaceur, I. Da Costa, R. Fournet, F. Billaud, F. Battin-Leclerc, Experimental and Modeling Study of the Oxidation of Toluene, Int. J. Chem. Kin., 37 (1) (2005) 25-49.

43 J. Herzler, M. Fikri, K. Hitzbleck, R. Starke, C. Schulz, P. Roth, G.T. Kalghatgi, Shock-tube study of the autoignition of n-heptane/toluene/air mixtures at intermediate temperatures and high pressures, Combust. Flame, 149 (2007) 25-31.

44 B.M. Gauthier, D.F. Davidson, R.K. Hanson, Shock tube determination of ignition delay times in full-blend and surrogate fuel mixtures, Combust. Flame 139 (2004) 300-311.

45 H. Machrafi, S. Cavadias, An energetic, kinetic and numerical analysis of the influence of the inlet temperature, equivalence ratio and compression ratio on the HCCI auto-ignition process of Primary Reference Fuels in an engine, Fuel Process. Tech. (2008), doi:10.1016/j.fuproc.2008.05.019. 


\section{Tables}

Table 1: Reduced chemical kinetic reaction scheme for $n$-heptane

\begin{tabular}{|c|c|c|c|c|c|}
\hline \multicolumn{6}{|c|}{$k=A T^{b} \exp \left(-E_{a} / R T\right)$} \\
\hline $\begin{array}{c}\text { Reaction } \\
\text { number }\end{array}$ & & Reaction & $\begin{array}{c}\text { A } \\
\text { [mole-cm- } \\
\text { s-K] }\end{array}$ & $\mathrm{b}[-]$ & $\begin{array}{c}E_{a} \\
{[\mathrm{~J} / \mathrm{mole}]}\end{array}$ \\
\hline 1 & \multicolumn{2}{|c|}{$\mathrm{C} 7 \mathrm{H} 16+\mathrm{O} 2=>\mathrm{C} 7 \mathrm{H} 15-2+\mathrm{HO} 2$} & $2,80 \mathrm{E}+14$ & 0,00 & 197533 \\
\hline 2 & \multicolumn{2}{|c|}{$\mathrm{C} 7 \mathrm{H} 16+\mathrm{OH}=>\mathrm{C} 7 \mathrm{H} 15-2+\mathrm{H} 2 \mathrm{O}$} & $4,80 \mathrm{E}+09$ & 1,30 & 2891 \\
\hline 3 & \multicolumn{2}{|c|}{$\mathrm{C} 7 \mathrm{H} 16+\mathrm{HO} 2=>\mathrm{C} 7 \mathrm{H} 15-2+\mathrm{H} 2 \mathrm{O} 2$} & $1,00 \mathrm{E}+13$ & 0,00 & 70966 \\
\hline 4 & \multicolumn{2}{|c|}{$\mathrm{C} 7 \mathrm{H} 15-2+\mathrm{O} 2=\mathrm{C} 7 \mathrm{H} 15 \mathrm{O} 2$} & $2,00 \mathrm{E}+12$ & 0,00 & 0 \\
\hline 5 & \multicolumn{2}{|c|}{$\mathrm{C} 7 \mathrm{H} 15 \mathrm{O} 2=\mathrm{C} 7 \mathrm{H} 14 \mathrm{O} 2 \mathrm{H}$} & $6,00 \mathrm{E}+11$ & 0,00 & 85327 \\
\hline 6 & \multicolumn{2}{|c|}{$\mathrm{C} 7 \mathrm{H} 14 \mathrm{O} 2 \mathrm{H}+\mathrm{O} 2=\mathrm{C} 7 \mathrm{H} 14 \mathrm{O} 2 \mathrm{HO} 2$} & $2,34 \mathrm{E}+11$ & 0,00 & 0 \\
\hline 7 & \multicolumn{2}{|c|}{$\mathrm{C} 7 \mathrm{H} 14 \mathrm{O} 2 \mathrm{HO} 2=>\mathrm{C} 7 \mathrm{KET} 21+\mathrm{OH}$} & $2,97 \mathrm{E}+13$ & 0,00 & 111788 \\
\hline 8 & \multicolumn{2}{|c|}{$\mathrm{C} 7 \mathrm{KET} 21=>\mathrm{C} 5 \mathrm{H} 11+\mathrm{CO}+\mathrm{CH} 2 \mathrm{O}+\mathrm{OH}$} & $1,00 \mathrm{E}+16$ & 0,00 & 177520 \\
\hline 9 & \multicolumn{2}{|c|}{$\mathrm{C} 5 \mathrm{H} 11=>\mathrm{C} 2 \mathrm{H} 5+\mathrm{C} 3 \mathrm{H} 6$} & $3,20 \mathrm{E}+13$ & 0,00 & 118486 \\
\hline 10 & \multicolumn{2}{|c|}{$\mathrm{C} 3 \mathrm{H} 6+\mathrm{OH}=>\mathrm{CH} 3 \mathrm{CHO}+\mathrm{CH} 3$} & $3,50 \mathrm{E}+11$ & 0,00 & 0 \\
\hline 11 & \multicolumn{2}{|c|}{$\mathrm{C} 2 \mathrm{H} 5+\mathrm{O} 2=>\mathrm{C} 2 \mathrm{H} 4+\mathrm{HO} 2$} & $2,00 \mathrm{E}+10$ & 0,00 & -9211 \\
\hline 12 & \multicolumn{2}{|c|}{$\mathrm{C} 2 \mathrm{H} 4+\mathrm{OH}=>\mathrm{CH} 2 \mathrm{O}+\mathrm{CH} 3$} & $6,00 \mathrm{E}+13$ & 0,00 & 4019 \\
\hline 13 & \multicolumn{2}{|c|}{$\mathrm{CH} 2 \mathrm{O}+\mathrm{OH}+\mathrm{O} 2=>\mathrm{H} 2 \mathrm{O}+\mathrm{HO} 2+\mathrm{CO}$} & $6,69 \mathrm{E}+14$ & 1,18 & -1871 \\
\hline 14 & \multicolumn{2}{|c|}{$\mathrm{CH} 3 \mathrm{CHO}+\mathrm{OH}+\mathrm{M}=>\mathrm{CH} 3+\mathrm{CO}+\mathrm{M}+\mathrm{H} 2 \mathrm{O}$} & $1,80 \mathrm{E}+17$ & 0,00 & 60290 \\
\hline 15 & \multicolumn{2}{|c|}{$\mathrm{CH} 3+\mathrm{HO} 2=>\mathrm{CH} 3 \mathrm{O}+\mathrm{OH}$} & $4,30 \mathrm{E}+13$ & 0,00 & 0 \\
\hline 16 & \multicolumn{2}{|c|}{$\mathrm{CH} 3 \mathrm{O}(+\mathrm{M})=\mathrm{CH} 2 \mathrm{O}+\mathrm{H}(+\mathrm{M})$} & $2,00 \mathrm{E}+13$ & 0,00 & 114802 \\
\hline & \multicolumn{2}{|c|}{ Low pressure limit } & $2,34 \mathrm{E}+25$ & $-2,70$ & 128116 \\
\hline 17 & \multicolumn{2}{|c|}{$\mathrm{O}+\mathrm{OH}=>\mathrm{O} 2+\mathrm{H}$} & $4,00 \mathrm{E}+14$ & $-0,50$ & 0 \\
\hline 18 & \multicolumn{2}{|c|}{$\mathrm{H}+\mathrm{O} 2+\mathrm{N} 2=>\mathrm{HO} 2+\mathrm{N} 2$} & $2,60 \mathrm{E}+19$ & $-1,24$ & 0 \\
\hline 19 & \multicolumn{2}{|c|}{$\mathrm{HO} 2+\mathrm{HO} 2=>\mathrm{H} 2 \mathrm{O} 2+\mathrm{O} 2$} & $2,00 \mathrm{E}+12$ & 0,00 & 0 \\
\hline 20 & \multicolumn{2}{|c|}{$\mathrm{OH}+\mathrm{OH}(+\mathrm{M})=\mathrm{H} 2 \mathrm{O} 2(+\mathrm{M})$} & $7,60 \mathrm{E}+13$ & $-0,37$ & 0 \\
\hline & \multicolumn{2}{|c|}{ Low pressure limit } & $4,30 \mathrm{E}+18$ & $-0,90$ & -7118 \\
\hline & \multicolumn{2}{|c|}{ Troe coefficients 0,$7346 ; 94 ; 1756 ; 5182$} & -- & -- & -- \\
\hline & \multicolumn{2}{|c|}{ Enhancement factors } & -- & -- & -- \\
\hline & & 2,00 & -- & -- & -- \\
\hline & $\mathrm{H} 2 \mathrm{O}$ & 6,00 & -- & -- & -- \\
\hline & $\mathrm{CH} 4$ & 2,00 & -- & -- & -- \\
\hline & $\mathrm{CO}$ & 1,50 & -- & -- & -- \\
\hline & $\mathrm{CO} 2$ & 2,00 & -- & -- & -- \\
\hline & & 0,70 & -- & -- & -- \\
\hline 21 & $\mathrm{CO}+\mathrm{C}$ & $=\mathrm{CO} 2+\mathrm{H}$ & $3,51 \mathrm{E}+07$ & 1,30 & -3174 \\
\hline
\end{tabular}


Table 2: Reduced chemical kinetic reaction scheme for iso-octane

\begin{tabular}{|c|c|c|c|c|c|}
\hline \multicolumn{6}{|c|}{$k=A T^{b} \exp \left(-E_{a} / R T\right)$} \\
\hline $\begin{array}{c}\text { Reaction } \\
\text { number }\end{array}$ & \multicolumn{2}{|c|}{ Reaction } & $\begin{array}{c}\mathrm{A} \\
{[\mathrm{mole}-\mathrm{cm}-\mathrm{s}-\mathrm{K}]}\end{array}$ & $\mathrm{b}[-]$ & Ea [J/mole] \\
\hline 1 & \multicolumn{2}{|c|}{$\mathrm{IC} 8 \mathrm{H} 18+\mathrm{O} 2+\mathrm{O} 2=>\mathrm{R} 2 \mathrm{C} 8 \mathrm{H} 17 \mathrm{OO}+\mathrm{HO} 2$} & $2,10 \mathrm{E}+17$ & 0 & 204820 \\
\hline 2 & \multicolumn{2}{|c|}{$\mathrm{IC} 8 \mathrm{H} 18+\mathrm{OH}=>\mathrm{CC} 8 \mathrm{H} 17+\mathrm{H} 2 \mathrm{O}$} & $2,48 E+13$ & 0 & 1839,2 \\
\hline 3 & \multicolumn{2}{|c|}{$\mathrm{IC} 8 \mathrm{H} 18+\mathrm{HO} 2=\mathrm{CC} 8 \mathrm{H} 17+\mathrm{H} 2 \mathrm{O} 2$} & $2,02 \mathrm{E}+12$ & 0 & 60192 \\
\hline 4 & \multicolumn{2}{|c|}{$\mathrm{CC} 8 \mathrm{H} 17+\mathrm{O} 2=\mathrm{R} 2 \mathrm{C} 8 \mathrm{H} 17 \mathrm{OO}$} & $2,50 \mathrm{E}+19$ & $-2,5$ & 0 \\
\hline 5 & \multicolumn{2}{|c|}{$\mathrm{R} 2 \mathrm{C} 8 \mathrm{H} 17 \mathrm{OO}=\mathrm{C} 8 \mathrm{H} 16 \mathrm{OOH}$} & $3,28 \mathrm{E}+12$ & 0 & 119130 \\
\hline & \multicolumn{2}{|c|}{ Reverse reaction } & $1,80 \mathrm{E}+11$ & 0 & 84018 \\
\hline 6 & \multicolumn{2}{|c|}{$\mathrm{C} 8 \mathrm{H} 16 \mathrm{OOH}+\mathrm{O} 2=\mathrm{R} 2 \mathrm{C} 8 \mathrm{H} 16 \mathrm{OOHOO}$} & $2,12 \mathrm{E}+19$ & $-2,5$ & 0 \\
\hline & \multicolumn{2}{|c|}{ Reverse reaction } & $7,00 \mathrm{E}+12$ & 0 & 91040,4 \\
\hline 7 & \multicolumn{2}{|c|}{$\mathrm{R} 2 \mathrm{C} 8 \mathrm{H} 16 \mathrm{OOHOO}=>\mathrm{OH}+\mathrm{C} 7 \mathrm{H} 14 \mathrm{CHO}(\mathrm{OOH})$} & $4,80 \mathrm{E}+12$ & 0 & 119130 \\
\hline 8 & \multicolumn{2}{|c|}{$\mathrm{C} 7 \mathrm{H} 14 \mathrm{CHO}(\mathrm{OOH})=>\mathrm{CO}+\mathrm{IC} 6 \mathrm{H} 13+\mathrm{CH} 2 \mathrm{O}+\mathrm{OH}$} & $2,05 \mathrm{E}+15$ & 0 & 173052 \\
\hline 9 & \multicolumn{2}{|c|}{$\mathrm{CC} 8 \mathrm{H} 17+\mathrm{HO} 2=>\mathrm{IC} 6 \mathrm{H} 13+\mathrm{C} 2 \mathrm{H} 3+\mathrm{H} 2 \mathrm{O} 2$} & $2,00 \mathrm{E}+12$ & 0 & 0 \\
\hline 10 & \multicolumn{2}{|c|}{$\mathrm{CC} 8 \mathrm{H} 17=>\mathrm{IC} 4 \mathrm{H} 8+\mathrm{IC} 4 \mathrm{H} 9$} & $4,28 \mathrm{E}+12$ & 0 & 115368 \\
\hline 11 & \multicolumn{2}{|c|}{$\mathrm{IC} 6 \mathrm{H} 13=>\mathrm{IC} 3 \mathrm{H} 7+\mathrm{C} 3 \mathrm{H} 6$} & $2,51 \mathrm{E}+13$ & 0 & 117876 \\
\hline 12 & \multicolumn{2}{|c|}{$\mathrm{IC} 4 \mathrm{H} 9+\mathrm{O} 2=>\mathrm{IC} 4 \mathrm{H} 8+\mathrm{HO} 2$} & $1,00 \mathrm{E}+12$ & 0 & 20900 \\
\hline 13 & \multicolumn{2}{|c|}{$\mathrm{IC} 4 \mathrm{H} 8+\mathrm{OH}=>\mathrm{IC} 3 \mathrm{H} 7+\mathrm{CH} 2 \mathrm{O}$} & $1,51 \mathrm{E}+12$ & 0 & 0 \\
\hline 14 & \multicolumn{2}{|c|}{$\mathrm{IC} 3 \mathrm{H} 7+\mathrm{O} 2=>\mathrm{C} 3 \mathrm{H} 6+\mathrm{HO} 2$} & $1,00 \mathrm{E}+12$ & 0 & 20900 \\
\hline 15 & \multicolumn{2}{|c|}{$\mathrm{C} 3 \mathrm{H} 6+\mathrm{OH}=>\mathrm{C} 2 \mathrm{H} 5+\mathrm{CH} 2 \mathrm{O}$} & $1,00 \mathrm{E}+12$ & 0 & 0 \\
\hline 16 & \multicolumn{2}{|c|}{$\mathrm{C} 2 \mathrm{H} 5+\mathrm{O} 2=>\mathrm{C} 2 \mathrm{H} 4+\mathrm{HO} 2$} & $1,00 \mathrm{E}+12$ & 0 & 20900 \\
\hline 17 & \multicolumn{2}{|c|}{$\mathrm{C} 2 \mathrm{H} 4+\mathrm{H}=>\mathrm{C} 2 \mathrm{H} 3+\mathrm{H} 2$} & $1,51 \mathrm{E}+07$ & 2 & 25080 \\
\hline 18 & \multicolumn{2}{|c|}{$\mathrm{C} 2 \mathrm{H} 3+\mathrm{O} 2=>\mathrm{CH} 2 \mathrm{O}+\mathrm{HCO}$} & $3,98 \mathrm{E}+12$ & 0 & -1045 \\
\hline 19 & \multicolumn{2}{|c|}{$\mathrm{CH} 2 \mathrm{O}+\mathrm{O} 2+\mathrm{M}=>\mathrm{H}+\mathrm{CO}+\mathrm{M}+\mathrm{HO} 2$} & $6,20 \mathrm{E}+16$ & 0 & 154660 \\
\hline 20 & $\mathrm{CH} 2 \mathrm{O}$ & & $2,17 \mathrm{E}+11$ & 0 & 33440 \\
\hline 21 & $\mathrm{HCO}+$ & & $3,98 \mathrm{E}+12$ & 0 & 0 \\
\hline 22 & $\mathrm{H} 2+\mathrm{O}$ & & $1,82 \mathrm{E}+10$ & 1 & 37202 \\
\hline 23 & $\mathrm{H} 2 \mathrm{O} 2$ & & $1,00 \mathrm{E}+13$ & 0 & 7524 \\
\hline & Rever & & $2,03 \mathrm{E}+13$ & 0 & 145798,4 \\
\hline 24 & $\mathrm{H} 2 \mathrm{O}+$ & & $2,19 \mathrm{E}+16$ & 0 & 438900 \\
\hline & Enhan & & -- & -- & -- \\
\hline & $\mathrm{H} 2 \mathrm{O}$ & 21 & -- & -- & -- \\
\hline & $\mathrm{CO}$ & 2,0 & -- & -- & -- \\
\hline & $\mathrm{H} 2$ & 3,3 & -- & -- & -- \\
\hline 25 & $\mathrm{HO} 2+$ & & $5,78 \mathrm{E}+12$ & 0 & 23700,6 \\
\hline 26 & $\mathrm{H} 2 \mathrm{O} 2$ & & $3,00 \mathrm{E}+14$ & 0 & 202730 \\
\hline & Low $p$ & & $2,00 \mathrm{E}+17$ & 0 & 202730 \\
\hline & TROE & 00000 & -- & -- & -- \\
\hline & Enhan & & -- & -- & -- \\
\hline & $\mathrm{H} 2$ & 2,0 & -- & -- & -- \\
\hline & $\mathrm{H} 2 \mathrm{O}$ & 12 & -- & -- & -- \\
\hline & $\mathrm{CO}$ & 1,9 & -- & -- & -- \\
\hline & $\mathrm{CO} 2$ & 3,8 & -- & -- & -- \\
\hline 27 & $\mathrm{CO}+\mathrm{H}$ & & $1,51 \mathrm{E}+14$ & 0 & 98857 \\
\hline 28 & $\mathrm{CO}+\mathrm{O}$ & & $5,89 \mathrm{E}+15$ & 0 & 17138 \\
\hline 29 & $\mathrm{CO} 2+$ & & $2,75 \mathrm{E}+12$ & 0 & 183209,4 \\
\hline & Rever & & $3,25 \mathrm{E}+11$ & 0 & 153280,6 \\
\hline & Rever & & $1,79 \mathrm{E}+13$ & 0 & 103747,6 \\
\hline
\end{tabular}


Table 3: Reduced chemical kinetic reaction scheme for toluene

\begin{tabular}{|c|c|c|c|c|}
\hline \multicolumn{5}{|c|}{$k=A T^{b} \exp \left(-E_{a} / R T\right)$} \\
\hline $\begin{array}{c}\text { Reaction } \\
\text { number }\end{array}$ & Reaction & $\begin{array}{c}\mathrm{A} \\
{[\mathrm{mole}-\mathrm{cm}-\mathrm{s}-\mathrm{K}]}\end{array}$ & $\mathrm{b}[-]$ & Ea $[\mathrm{J} / \mathrm{mole}]$ \\
\hline 1 & $\mathrm{C} 6 \mathrm{H} 5 \mathrm{CH} 3+\mathrm{O} 2=\mathrm{C} 6 \mathrm{H} 5 \mathrm{CH} 2+\mathrm{HO} 2$ & $3,00 \mathrm{E}+14$ & 0 & 179706,56 \\
\hline 2 & $\mathrm{C} 6 \mathrm{H} 5 \mathrm{CH} 3+\mathrm{OH}=\mathrm{C} 6 \mathrm{H} 5 \mathrm{CH} 2+\mathrm{H} 2 \mathrm{O}$ & $5,27 \mathrm{E}+13$ & 0 & 10796,94 \\
\hline 3 & $\mathrm{C} 6 \mathrm{H} 5 \mathrm{CH} 2+\mathrm{HO} 2=\mathrm{C} 6 \mathrm{H} 5 \mathrm{CHO}+\mathrm{H}+\mathrm{OH}$ & $5,00 \mathrm{E}+12$ & 0 & 0 \\
\hline 4 & $\mathrm{C} 6 \mathrm{H} 5 \mathrm{CHO}+\mathrm{OH}=\mathrm{C} 6 \mathrm{H} 5 \mathrm{CO}+\mathrm{H} 2 \mathrm{O}$ & $1,61 \mathrm{E}+09$ & 1,18 & $-1868,46$ \\
\hline 5 & $\mathrm{C} 6 \mathrm{H} 5 \mathrm{CO}=\mathrm{C} 6 \mathrm{H} 5+\mathrm{CO}$ & $3,98 \mathrm{E}+14$ & 0 & 122892 \\
\hline 6 & $\mathrm{C} 6 \mathrm{H} 5+\mathrm{O} 2=\mathrm{C} 6 \mathrm{H} 5 \mathrm{O}+\mathrm{O}$ & $2,60 \mathrm{E}+13$ & 0 & 25581,6 \\
\hline 7 & $\mathrm{C} 6 \mathrm{H} 5 \mathrm{O}=\mathrm{CO}+\mathrm{C} 5 \mathrm{H} 5$ & $3,76 \mathrm{E}+54$ & $-12,06$ & 310574 \\
\hline 8 & $\mathrm{C} 5 \mathrm{H} 5+\mathrm{O} 2=\mathrm{C} 5 \mathrm{H} 4 \mathrm{O}+\mathrm{OH}$ & $1,80 \mathrm{E}+12$ & 0,08 & 75240 \\
\hline 9 & $\mathrm{C} 5 \mathrm{H} 4 \mathrm{O}+\mathrm{O}+2 \mathrm{O} 2=3 \mathrm{CO}+2 \mathrm{HCO}+\mathrm{H} 2 \mathrm{O}$ & $3,60 \mathrm{E}+16$ & 1,45 & $-3586,44$ \\
\hline 10 & $\mathrm{H}+\mathrm{O} 2=\mathrm{HO} 2$ & $2,07 \mathrm{E}+18$ & $-1,69$ & 3720,2 \\
\hline 11 & $\mathrm{HO} 2+\mathrm{HO} 2=\mathrm{H} 2 \mathrm{O} 2+\mathrm{O} 2$ & $3,22 \mathrm{E}+11$ & 0 & $-6809,22$ \\
\hline 12 & $\mathrm{OH}+\mathrm{OH}=\mathrm{H} 2 \mathrm{O} 2$ & $1,00 \mathrm{E}+29$ & $-5,452$ & 12832,6 \\
\hline 13 & $\mathrm{OH}+\mathrm{HO} 2=\mathrm{H} 2 \mathrm{O}+\mathrm{O} 2$ & $1,91 \mathrm{E}+16$ & -1 & 0 \\
\hline 14 & $\mathrm{H}+\mathrm{O} 2=\mathrm{OH}+\mathrm{O}$ & $2,10 E+15$ & $-0,3$ & 84436 \\
\hline 15 & $\mathrm{OH}+\mathrm{OH}=\mathrm{O}+\mathrm{H} 2 \mathrm{O}$ & $1,50 \mathrm{E}+09$ & 1,14 & 415,492 \\
\hline 16 & $\mathrm{HCO}+\mathrm{M}=\mathrm{H}+\mathrm{CO}+\mathrm{M}$ & $2,50 \mathrm{E}+14$ & 0 & 70232,36 \\
\hline 17 & $\mathrm{CO}+\mathrm{O}=\mathrm{CO} 2$ & $1,80 \mathrm{E}+10$ & 0 & 10190,84 \\
\hline 18 & $\mathrm{CO}+\mathrm{OH}=\mathrm{CO} 2+\mathrm{H}$ & $3,09 \mathrm{E}+11$ & 0 & 3072,3 \\
\hline
\end{tabular}


Table 4: Reduced chemical kinetic reaction scheme of surrogates of n-heptane, iso-octane and

toluene for gasoline and diesel applications

\begin{tabular}{|c|c|c|c|c|}
\hline \multicolumn{5}{|c|}{$k=A T^{b} \exp \left(-E_{a} / R T\right)$} \\
\hline $\begin{array}{c}\text { Reaction } \\
\text { number }\end{array}$ & Reaction & $\begin{array}{c}\mathrm{A} \\
\text { [mole-cm-s-K] }\end{array}$ & $\mathrm{b}[-]$ & Ea $[\mathrm{J} / \mathrm{mole}]$ \\
\hline Reactions & N-heptane initiation reactions & & & \\
\hline 1 & $\mathrm{C} 7 \mathrm{H} 16+\mathrm{O} 2=>\mathrm{C} 7 \mathrm{H} 15-2+\mathrm{HO} 2$ & $2,80 E+14$ & 0 & 197212,4 \\
\hline 2 & $\mathrm{C} 7 \mathrm{H} 16+\mathrm{OH}=>\mathrm{C} 7 \mathrm{H} 15-2+\mathrm{H} 2 \mathrm{O}$ & $4,80 \mathrm{E}+09$ & 1,3 & 2886,29 \\
\hline 3 & $\mathrm{C} 7 \mathrm{H} 16+\mathrm{HO} 2=>\mathrm{C} 7 \mathrm{H} 15-2+\mathrm{H} 2 \mathrm{O} 2$ & $1,00 \mathrm{E}+13$ & 0 & 70851 \\
\hline 4 & $\mathrm{C} 7 \mathrm{H} 15-2+\mathrm{O} 2=\mathrm{C} 7 \mathrm{H} 15 \mathrm{O} 2$ & $2,00 \mathrm{E}+12$ & 0 & 0 \\
\hline 5 & $\mathrm{C} 7 \mathrm{H} 15 \mathrm{O} 2=\mathrm{C} 7 \mathrm{H} 14 \mathrm{O} 2 \mathrm{H}$ & $6,00 \mathrm{E}+11$ & 0 & 85188,4 \\
\hline 6 & $\mathrm{C} 7 \mathrm{H} 14 \mathrm{O} 2 \mathrm{H}+\mathrm{O} 2=\mathrm{C} 7 \mathrm{H} 14 \mathrm{O} 2 \mathrm{HO} 2$ & $2,34 \mathrm{E}+11$ & 0 & 0 \\
\hline 7 & $\mathrm{C} 7 \mathrm{H} 14 \mathrm{O} 2 \mathrm{HO} 2=>\mathrm{C} 7 \mathrm{KET} 21+\mathrm{OH}$ & $2,97 \mathrm{E}+13$ & 0 & 111606 \\
\hline 8 & C7KET21=>C5H11+CO+CH2O+OH & $1,00 \mathrm{E}+16$ & 0 & 177232 \\
\hline 9 & $\mathrm{C} 5 \mathrm{H} 11=>\mathrm{C} 2 \mathrm{H} 5+\mathrm{C} 3 \mathrm{H} 6$ & $3,20 \mathrm{E}+13$ & 0 & 118294 \\
\hline 10 & $\mathrm{C} 3 \mathrm{H} 6+\mathrm{OH}=>\mathrm{CH} 3 \mathrm{CHO}+\mathrm{CH} 3$ & $3,50 \mathrm{E}+11$ & 0 & 0 \\
\hline Reactions & Iso-octane initiation reactions & & & \\
\hline 11 & $\mathrm{IC} 8 \mathrm{H} 18+\mathrm{O} 2+\mathrm{O} 2=>\mathrm{R} 2 \mathrm{C} 8 \mathrm{H} 17 \mathrm{OO}+\mathrm{HO} 2$ & $2,10 \mathrm{E}+17$ & 0 & 204820 \\
\hline 12 & $\mathrm{IC} 8 \mathrm{H} 18+\mathrm{OH}=>\mathrm{CC} 8 \mathrm{H} 17+\mathrm{H} 2 \mathrm{O}$ & $2,48 \mathrm{E}+13$ & 0 & 1839,2 \\
\hline 13 & $\mathrm{IC} 8 \mathrm{H} 18+\mathrm{HO} 2=\mathrm{CC} 8 \mathrm{H} 17+\mathrm{H} 2 \mathrm{O} 2$ & $2,02 \mathrm{E}+12$ & 0 & 60192 \\
\hline 14 & $\mathrm{CC} 8 \mathrm{H} 17+\mathrm{O} 2=\mathrm{R} 2 \mathrm{C} 8 \mathrm{H} 17 \mathrm{OO}$ & $2,50 \mathrm{E}+19$ & $-2,5$ & 0 \\
\hline & Reverse reaction & $1,79 \mathrm{E}+13$ & 0 & 103747,6 \\
\hline 15 & $\mathrm{R} 2 \mathrm{C} 8 \mathrm{H} 17 \mathrm{OO}=\mathrm{C} 8 \mathrm{H} 16 \mathrm{OOH}$ & $3,28 \mathrm{E}+12$ & 0 & 119130 \\
\hline & Reverse reaction & $1,80 \mathrm{E}+11$ & 0 & 84018 \\
\hline 16 & $\mathrm{C} 8 \mathrm{H} 16 \mathrm{OOH}+\mathrm{O} 2=\mathrm{R} 2 \mathrm{C} 8 \mathrm{H} 16 \mathrm{OOHOO}$ & $3,52 \mathrm{E}+19$ & $-2,5$ & 0 \\
\hline & Reverse reaction & $7,00 \mathrm{E}+12$ & 0 & 91040,4 \\
\hline 17 & $\mathrm{R} 2 \mathrm{C} 8 \mathrm{H} 16 \mathrm{OOHOO}=>\mathrm{OH}+\mathrm{C} 7 \mathrm{H} 14 \mathrm{CHO}(\mathrm{OOH})$ & $4,80 \mathrm{E}+12$ & 0 & 119130 \\
\hline 18 & $\mathrm{C} 7 \mathrm{H} 14 \mathrm{CHO}(\mathrm{OOH})=>\mathrm{CO}+\mathrm{IC} 6 \mathrm{H} 13+\mathrm{CH} 2 \mathrm{O}+\mathrm{OH}$ & $2,05 \mathrm{E}+15$ & 0 & 173052 \\
\hline 19 & $\mathrm{CC} 8 \mathrm{H} 17+\mathrm{HO} 2=>1 \mathrm{C} 6 \mathrm{H} 13+\mathrm{C} 2 \mathrm{H} 3+\mathrm{H} 2 \mathrm{O} 2$ & $2,00 \mathrm{E}+12$ & 0 & 0 \\
\hline 20 & $\mathrm{CC} 8 \mathrm{H} 17=>\mathrm{IC} 4 \mathrm{H} 8+\mid \mathrm{C} 4 \mathrm{H} 9$ & $4,28 \mathrm{E}+12$ & 0 & 115368 \\
\hline 21 & $\mathrm{IC} 6 \mathrm{H} 13=>\mathrm{IC} 3 \mathrm{H} 7+\mathrm{C} 3 \mathrm{H} 6$ & $2,51 \mathrm{E}+13$ & 0 & 117876 \\
\hline 22 & $\mathrm{IC} 4 \mathrm{H} 9+\mathrm{O} 2=>\mathrm{IC} 4 \mathrm{H} 8+\mathrm{HO} 2$ & $1,00 \mathrm{E}+12$ & 0 & 20900 \\
\hline 23 & $\mathrm{IC} 4 \mathrm{H} 8+\mathrm{OH}=>\mathrm{IC} 3 \mathrm{H} 7+\mathrm{CH} 2 \mathrm{O}$ & $1,51 \mathrm{E}+12$ & 0 & 0 \\
\hline 24 & $\mathrm{IC} 3 \mathrm{H} 7+\mathrm{O} 2=>\mathrm{C} 3 \mathrm{H} 6+\mathrm{HO} 2$ & $1,00 \mathrm{E}+12$ & 0 & 20900 \\
\hline 25 & $\mathrm{C} 3 \mathrm{H} 6+\mathrm{OH}=>\mathrm{C} 2 \mathrm{H} 5+\mathrm{CH} 2 \mathrm{O}$ & $1,00 \mathrm{E}+12$ & 0 & 0 \\
\hline Reactions & Toluene initiation reactions & & & \\
\hline 26 & $\mathrm{C} 6 \mathrm{H} 5 \mathrm{CH} 3+\mathrm{O} 2=\mathrm{C} 6 \mathrm{H} 5 \mathrm{CH} 2+\mathrm{HO} 2$ & $3,00 \mathrm{E}+14$ & 0 & 179706,56 \\
\hline 27 & $\mathrm{C} 6 \mathrm{H} 5 \mathrm{CH} 3+\mathrm{OH}=>\mathrm{C} 6 \mathrm{H} 5 \mathrm{CH} 2+\mathrm{H} 2 \mathrm{O}$ & $5,27 \mathrm{E}+13$ & 0 & 10796,94 \\
\hline 28 & $\mathrm{C} 6 \mathrm{H} 5 \mathrm{CH} 2+\mathrm{HO} 2=>\mathrm{C} 6 \mathrm{H} 5 \mathrm{CHO}+\mathrm{H}+\mathrm{OH}$ & $5,00 \mathrm{E}+12$ & 0 & 0 \\
\hline 29 & $\mathrm{C} 6 \mathrm{H} 5 \mathrm{CHO}+\mathrm{OH}=>\mathrm{C} 6 \mathrm{H} 5 \mathrm{CO}+\mathrm{H} 2 \mathrm{O}$ & $2,25 E+10$ & 1,18 & $-1868,46$ \\
\hline 30 & $\mathrm{C} 6 \mathrm{H} 5 \mathrm{CO}=>\mathrm{C} 6 \mathrm{H} 5+\mathrm{CO}$ & $3,98 \mathrm{E}+14$ & 0 & 122892 \\
\hline 31 & $\mathrm{C} 6 \mathrm{H} 5+\mathrm{O} 2=>\mathrm{C} 6 \mathrm{H} 5 \mathrm{O}+\mathrm{O}$ & $2,60 \mathrm{E}+13$ & 0 & 25581,6 \\
\hline 32 & $\mathrm{C} 6 \mathrm{H} 5 \mathrm{O}=>\mathrm{CO}+\mathrm{C} 5 \mathrm{H} 5$ & $3,76 \mathrm{E}+54$ & $-12,06$ & 310574 \\
\hline 33 & $\mathrm{C} 5 \mathrm{H} 5+\mathrm{O} 2=>\mathrm{C} 5 \mathrm{H} 4 \mathrm{O}+\mathrm{OH}$ & $1,80 \mathrm{E}+12$ & 0,08 & 75240 \\
\hline 34 & $\mathrm{C} 5 \mathrm{H} 4 \mathrm{O}+\mathrm{O}+2 \mathrm{O} 2=>3 \mathrm{CO}+2 \mathrm{HCO}+\mathrm{H} 2 \mathrm{O}$ & $3,60 \mathrm{E}+16$ & 1,45 & $-3586,44$ \\
\hline Reactions & C2 reactions & & & \\
\hline 35 & $\mathrm{C} 2 \mathrm{H} 5+\mathrm{O} 2=>\mathrm{C} 2 \mathrm{H} 4+\mathrm{HO} 2$ & $2,00 \mathrm{E}+10$ & 0 & -9196 \\
\hline 36 & $\mathrm{C} 2 \mathrm{H} 4+\mathrm{OH}=>\mathrm{CH} 2 \mathrm{O}+\mathrm{CH} 3$ & $6,00 \mathrm{E}+13$ & 0 & 4012,8 \\
\hline 37 & $\mathrm{C} 2 \mathrm{H} 4+\mathrm{H}=>\mathrm{C} 2 \mathrm{H} 3+\mathrm{H} 2$ & $1,51 \mathrm{E}+07$ & 2 & 25080 \\
\hline 38 & $\mathrm{C} 2 \mathrm{H} 3+\mathrm{O} 2=>\mathrm{CH} 2 \mathrm{O}+\mathrm{HCO}$ & $3,98 \mathrm{E}+12$ & 0 & -1045 \\
\hline 39 & $\mathrm{CH} 3 \mathrm{CHO}+\mathrm{OH}+\mathrm{M}=>\mathrm{CH} 3+\mathrm{CO}+\mathrm{M}+\mathrm{H} 2 \mathrm{O}$ & $1,80 \mathrm{E}+17$ & 0 & 60192 \\
\hline Reactions & C1 reactions & & & \\
\hline 40 & $\mathrm{CH} 3+\mathrm{HO} 2=>\mathrm{CH} 3 \mathrm{O}+\mathrm{OH}$ & $4,30 \mathrm{E}+13$ & 0 & 0 \\
\hline 41 & $\mathrm{CH} 3 \mathrm{O}(+\mathrm{M})=\mathrm{CH} 2 \mathrm{O}+\mathrm{H}(+\mathrm{M})$ & $2,00 E+13$ & 0 & 114615,6 \\
\hline & Low pressure limit & $2,34 \mathrm{E}+25$ & $-2,7$ & 127908 \\
\hline
\end{tabular}




\begin{tabular}{|c|c|c|c|c|c|}
\hline 42 & \multicolumn{2}{|c|}{$\mathrm{CH} 2 \mathrm{O}+\mathrm{OH}+\mathrm{O} 2=>\mathrm{H} 2 \mathrm{O}+\mathrm{HO} 2+\mathrm{CO}$} & $6,69 \mathrm{E}+14$ & 1,18 & $-1868,46$ \\
\hline 43 & \multicolumn{2}{|c|}{$\mathrm{CH} 2 \mathrm{O}+\mathrm{O} 2+\mathrm{M}=>\mathrm{H}+\mathrm{CO}+\mathrm{M}+\mathrm{HO} 2$} & $6,20 \mathrm{E}+16$ & 0 & 154660 \\
\hline 44 & \multicolumn{2}{|c|}{$\mathrm{CH} 2 \mathrm{O}+\mathrm{HO} 2=>\mathrm{HCO}+\mathrm{H}_{2} \mathrm{O} 2$} & $2,17 \mathrm{E}+11$ & 0 & 33440 \\
\hline 45 & \multicolumn{2}{|c|}{$\mathrm{HCO}+\mathrm{O} 2=>\mathrm{CO}+\mathrm{HO} 2$} & $3,98 \mathrm{E}+12$ & 0 & 0 \\
\hline 46 & \multicolumn{2}{|c|}{$\mathrm{HCO}+\mathrm{M}=\mathrm{H}+\mathrm{CO}+\mathrm{M}$} & $2,50 \mathrm{E}+14$ & 0 & 70232,36 \\
\hline 47 & \multicolumn{2}{|c|}{$\mathrm{CO}+\mathrm{HO} 2=>\mathrm{CO} 2+\mathrm{OH}$} & $1,51 \mathrm{E}+14$ & 0 & 98857 \\
\hline 48 & \multicolumn{2}{|c|}{$\mathrm{CO}+\mathrm{O}=\mathrm{CO} 2$} & $1,80 \mathrm{E}+10$ & 0 & 10190,84 \\
\hline 49 & \multicolumn{2}{|c|}{$\mathrm{CO}+\mathrm{O}+\mathrm{M}=\mathrm{CO} 2+\mathrm{M}$} & $5,89 \mathrm{E}+15$ & 0 & 17138 \\
\hline 50 & \multicolumn{2}{|c|}{$\mathrm{CO}+\mathrm{OH}=\mathrm{CO} 2+\mathrm{H}$} & $3,09 \mathrm{E}+11$ & 0 & 3072,3 \\
\hline 51 & \multicolumn{2}{|c|}{$\mathrm{CO} 2+\mathrm{O}=\mathrm{CO}+\mathrm{O} 2$} & $2,75 \mathrm{E}+12$ & 0 & 183209,4 \\
\hline & \multicolumn{2}{|c|}{ Reverse reaction } & $3,25 \mathrm{E}+11$ & 0 & 153280,6 \\
\hline Reactions & \multicolumn{2}{|c|}{$\mathrm{O} / \mathrm{H}$ reactions } & & & \\
\hline 52 & \multicolumn{2}{|c|}{$\mathrm{HO} 2+\mathrm{HO} 2=\mathrm{H} 2 \mathrm{O} 2+\mathrm{O} 2$} & $3,22 \mathrm{E}+15$ & 0 & $-6809,22$ \\
\hline 53 & \multicolumn{2}{|c|}{$\mathrm{H} 2+\mathrm{O}=>\mathrm{H}+\mathrm{OH}$} & $1,82 \mathrm{E}+10$ & 1 & 37202 \\
\hline 54 & \multicolumn{2}{|c|}{$\mathrm{H} 2 \mathrm{O} 2+\mathrm{OH}=\mathrm{H} 2 \mathrm{O}+\mathrm{HO} 2$} & $1,00 \mathrm{E}+13$ & 0 & 7524 \\
\hline & \multicolumn{2}{|c|}{ Reverse reaction } & $2,03 \mathrm{E}+13$ & 0 & 145798,4 \\
\hline 55 & \multicolumn{2}{|c|}{$\mathrm{H} 2 \mathrm{O}+\mathrm{M}=\mathrm{H}+\mathrm{OH}+\mathrm{M}$} & $2,19 \mathrm{E}+16$ & 0 & 438900 \\
\hline & \multicolumn{2}{|c|}{ Enhancement factors: } & -- & -- & -- \\
\hline & $\mathrm{H} 2 \mathrm{O}$ & 21 & -- & -- & -- \\
\hline & $\mathrm{CO}$ & 2,0 & -- & -- & -- \\
\hline & $\mathrm{H} 2$ & 3,3 & -- & -- & -- \\
\hline 56 & \multicolumn{2}{|c|}{$\mathrm{H}+\mathrm{O} 2+\mathrm{N} 2=>\mathrm{HO} 2+\mathrm{N} 2$} & $2,60 \mathrm{E}+19$ & $-1,24$ & 0 \\
\hline 57 & \multicolumn{2}{|c|}{$\mathrm{H}+\mathrm{O} 2=\mathrm{HO} 2$} & $2,07 E+18$ & $-1,69$ & 3720,2 \\
\hline 58 & \multicolumn{2}{|c|}{$\mathrm{OH}+\mathrm{HO} 2=\mathrm{H} 2 \mathrm{O}+\mathrm{O} 2$} & $1,91 \mathrm{E}+16$ & -1 & 0 \\
\hline 59 & \multicolumn{2}{|c|}{$\mathrm{H}+\mathrm{O} 2=\mathrm{OH}+\mathrm{O}$} & $2,10 \mathrm{E}+15$ & $-0,3$ & 84436 \\
\hline 60 & \multicolumn{2}{|c|}{$\mathrm{OH}+\mathrm{OH}=\mathrm{O}+\mathrm{H} 2 \mathrm{O}$} & $1,50 \mathrm{E}+09$ & 1,14 & 415,492 \\
\hline 61 & \multicolumn{2}{|c|}{$\mathrm{OH}+\mathrm{OH}=\mathrm{H} 2 \mathrm{O} 2$} & $1,00 \mathrm{E}+25$ & $-5,452$ & 12832,6 \\
\hline 62 & \multicolumn{2}{|c|}{$\mathrm{OH}+\mathrm{OH}(+\mathrm{M})=\mathrm{H} 2 \mathrm{O} 2(+\mathrm{M})$} & $7,60 \mathrm{E}+13$ & $-0,37$ & -8151 \\
\hline & \multicolumn{2}{|c|}{ Low pressure limit } & $4,30 \mathrm{E}+18$ & $-0,9$ & -7106 \\
\hline & \multicolumn{2}{|c|}{ TROE coefficients 0,$7346 ; 94 ; 1756 ; 5182$} & -- & -- & -- \\
\hline & \multicolumn{2}{|c|}{ Enhancement factors: } & -- & -- & -- \\
\hline & $\mathrm{H} 2$ & 2,0 & -- & -- & -- \\
\hline & $\mathrm{H} 2 \mathrm{O}$ & 6,0 & -- & -- & -- \\
\hline & $\mathrm{CH} 4$ & 2,0 & -- & -- & -- \\
\hline & $\mathrm{CO}$ & 1,5 & -- & -- & -- \\
\hline & $\mathrm{CO} 2$ & 2,0 & -- & -- & -- \\
\hline & N2 & 0,7 & -- & -- & -- \\
\hline
\end{tabular}


Table 5: Numerical domain of validity of the surrogate mechanism with respect to the detailed mechanisms

\begin{tabular}{|l|l|l|l|}
\hline \multirow{2}{*}{ Parameter } & \multicolumn{3}{|c|}{ FUEL } \\
\cline { 2 - 4 } & $\mathrm{C}_{7} \mathrm{H}_{16}$ & $\mathrm{IC}_{8} \mathrm{H}_{18}$ & $\mathrm{C}_{6} \mathrm{H}_{5} \mathrm{CH}_{3}$ \\
\hline Inlet temperature [K] & $310-390$ & $310-390$ & $420-500$ \\
\hline Equivalence ratio [-] & $0.2-0.7$ & $0.2-0.7$ & $0.5-0.7$ \\
\hline Compression ratio [-] & $6-18$ & $12-18$ & $14-20$ \\
\hline
\end{tabular}




\section{Figure captions}

Figure 1: Ignition delays calculated by different mechanisms at compression ratio of 12, equivalence ratio of 0.2 for $n$-heptane

Figure 2: Comparison of the errors of the final ignition as a function of the equivalence ratio, the compression ratio, the inlet temperature and the fuels, n-heptane (top two with compression ratio 10,2 at the left and inlet temperature $340 \mathrm{~K}$ at the right), iso-octane (middle two with compression ratio 10.2 at the left and inlet temperature $340 \mathrm{~K}$ at the right) and toluene (bottom two with compression ratio 14 at the left and inlet temperature $400 \mathrm{~K}$ at the right)

Figure 3: Pressures and heat releases calculated with different mechanisms at compression ratio of 12 , equivalence ratio of 0.2 and an initial temperature of $365 \mathrm{~K}$, with n-heptane as the fuel

Figure 4: $\mathrm{CH}_{2} \mathrm{O}$ concentrations calculated with different mechanisms at compression ratio of 10, equivalence ratio of 0.4 and an initial temperature of $343 \mathrm{~K}$, with n-heptane as the fuel

Figure 5: $\mathrm{OH}$ concentrations calculated by different mechanisms for iso-octane at compression ratio of 15 , equivalence ratio of 0.6 and an initial temperature of $365 \mathrm{~K}$ and for toluene at compression ratio of 16 , equivalence ratio of 0.5 and an initial temperature of 500 $\mathrm{K}$, with toluene as the fuel

Figure 6: Comparison of the surrogate mechanism, the Chalmers mechanism and experimental data for a stoichiometric iso-octane/air mixture [7] (left y-axis), varying the initial temperature in a shock tube at a pressure of 10 bar and for an equivalence ratio (= fi) of 0.5 [35] (right y-axis), varying the initial temperature in a shock tube at a pressure of $40 \mathrm{bar}$

Figure 7: Comparison of the surrogate mechanism, the Chalmers mechanisms (n-heptane + iso-octane) and experimental data from [35], varying the initial temperature in a shock tube at a pressure of 40 bar with a stoichiometric PRF60/air mixture 
Figure 8: Comparison of the surrogate mechanism and the Chalmers mechanism and experimental data [26], varying the initial temperature in a shock tube at a pressure of 30 bar for a stoichiometric n-heptane/air mixture

Figure 9: Comparison of the surrogate mechanism and the Djurisic mechanism and experimental data (for 9 bar in a rapid compression machine [37] and for 9.5 bar in a shock tube [38]), varying the initial temperature in a constant volume reactor at a pressure of 9 bar for a stoichiometric toluene/air mixture

Figure 10: Comparison of the surrogate mechanism and experimental data [39], varying the initial temperature in a shock tube at pressures of 10 and 30 bar with 35 vol\% n-heptane and $65 \mathrm{vol} \%$ toluene at stiochiometric conditions

Figure 11: Comparison of the surrogate mechanism and the Djurisic mechanism and experimental data [40] for equivalence ratios (= fi) of 1.0 (left y-axis) and 0.5 (right y-axis), varying the initial temperature in a shock tube at a pressure of 20 and 55 bar with a gasoline surrogate as the fuel composed out of $17 \mathrm{vol} \%$ n-heptane, $63 \mathrm{vol} \%$ iso-octane and $20 \mathrm{vol} \%$ toluene

Figure 12: Comparison of the experimental and simulated pressure and heat release profiles using the gasoline surrogate at an inlet temperature of $70{ }^{\circ} \mathrm{C}$, a compression ratio of 13.5 and an equivalence ratio of 0.46

Figure 13: The global reaction scheme for the surrogate mechanism at the moment of the cool flame for a ternary gasoline surrogate composed out of $17 \mathrm{vol} \% \mathrm{n}$-heptane, $63 \mathrm{vol} \%$ isooctane and $20 \mathrm{vol} \%$ toluene

Figure 14: The global reaction scheme for the gasoline surrogate mechanism during the NTC region for a ternary gasoline surrogate composed out of 17 vol\% n-heptane, $63 \mathrm{vol} \%$ isooctane and 20 vol $\%$ toluene 
Figure 15: The global reaction scheme for the gasoline surrogate mechanism at the moment of the final ignition for a ternary gasoline surrogate composed out of 17 vol\% n-heptane, 63 vol $\%$ iso-octane and 20 vol $\%$ toluene 


\section{Figures}

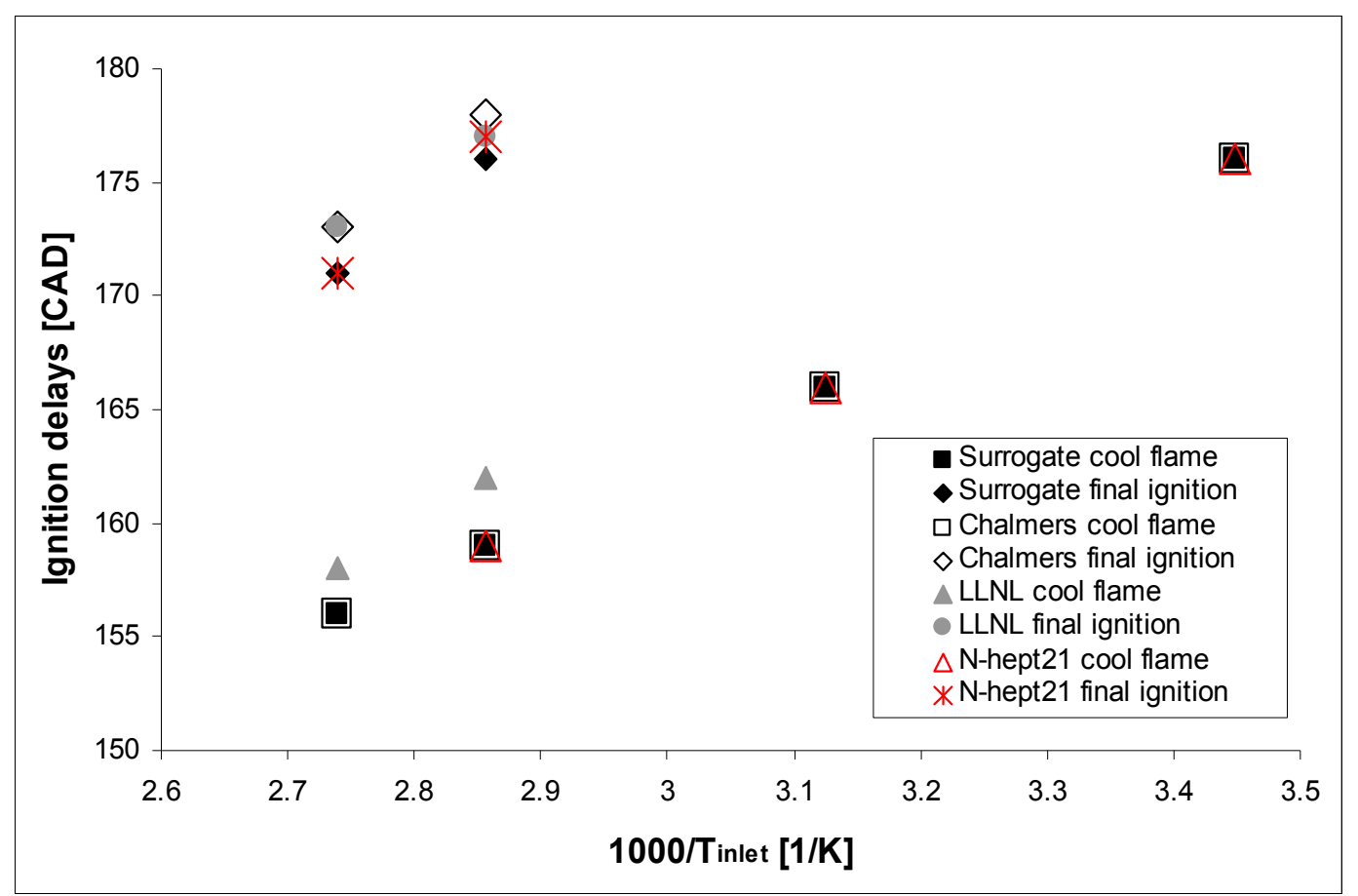

Figure 1: Ignition delays calculated by different mechanisms at compression ratio of 12, equivalence ratio of 0.2 for $n$-heptane 

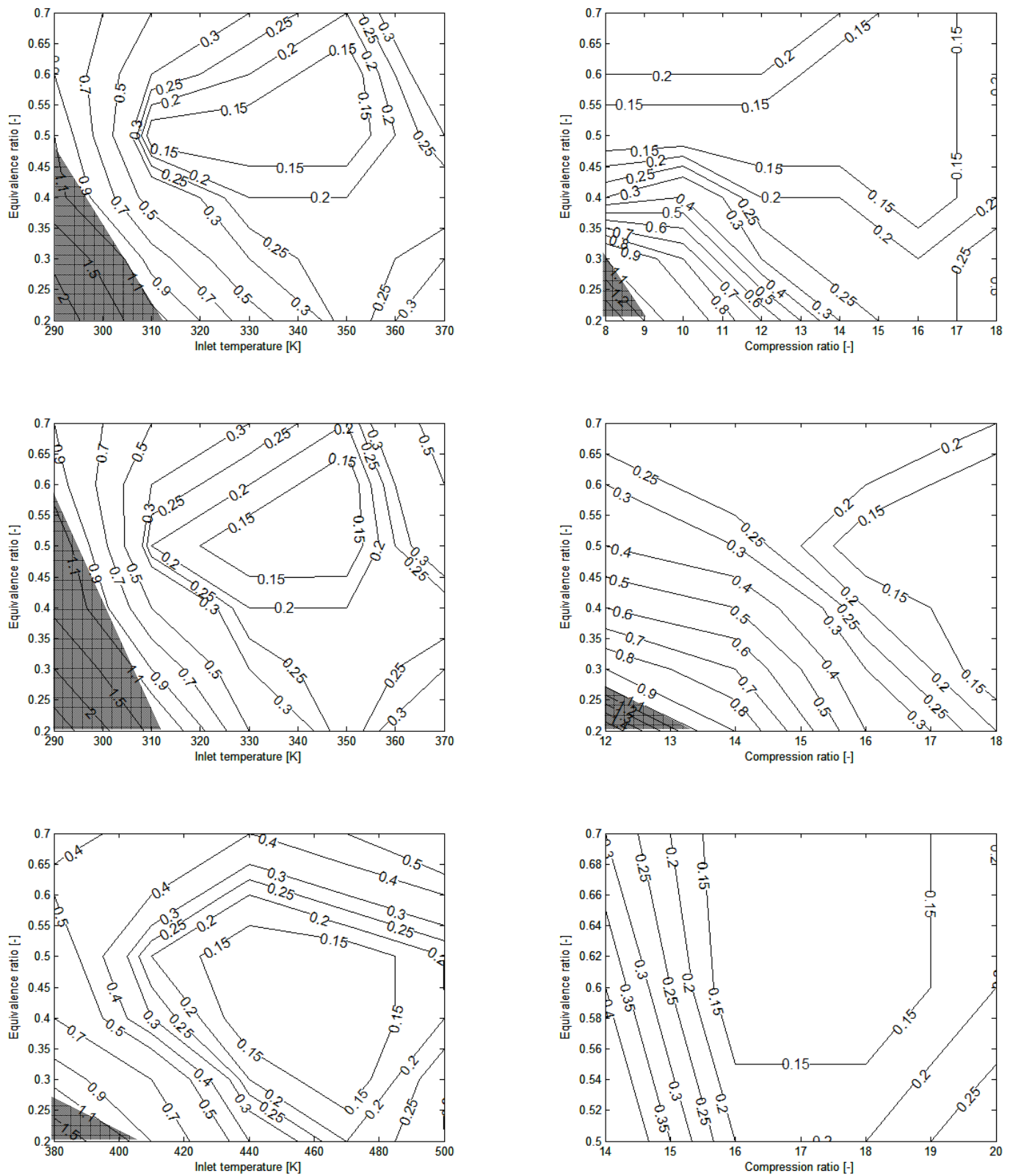

Figure 2: Comparison of the errors of the final ignition as a function of the equivalence ratio, the compression ratio, the inlet temperature and the fuels, n-heptane (top two with compression ratio 10,2 at the left and inlet temperature $340 \mathrm{~K}$ at the right), iso-octane (middle two with compression ratio 10.2 at the left and inlet temperature $340 \mathrm{~K}$ at the right) and toluene (bottom two with compression ratio 14 at the left and inlet temperature $400 \mathrm{~K}$ at the right) 


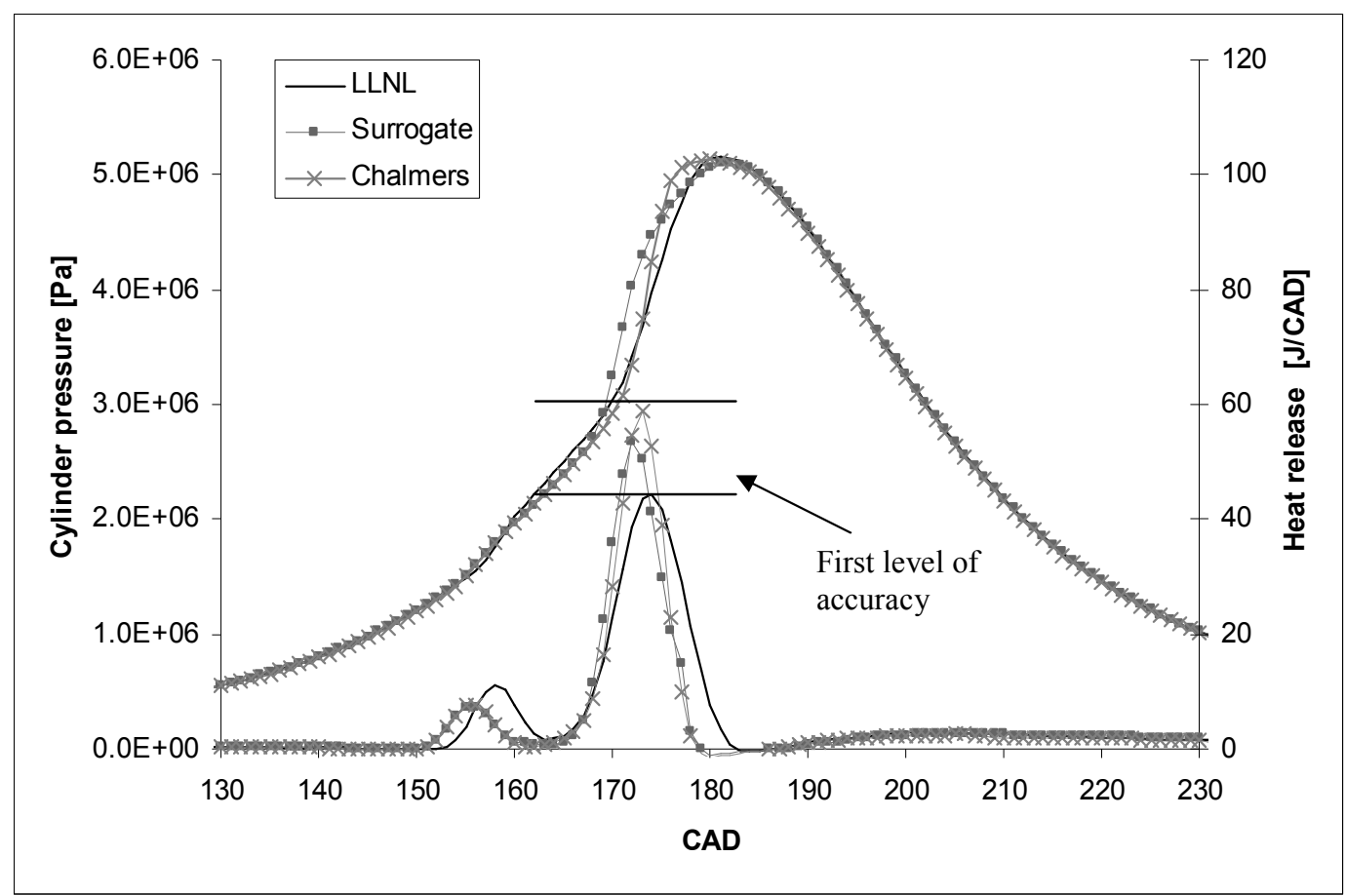

Figure 3: Pressures and heat releases calculated with different mechanisms at compression ratio of 12, equivalence ratio of 0.2 and an initial temperature of $365 \mathrm{~K}$, with $n$-heptane as the fuel 


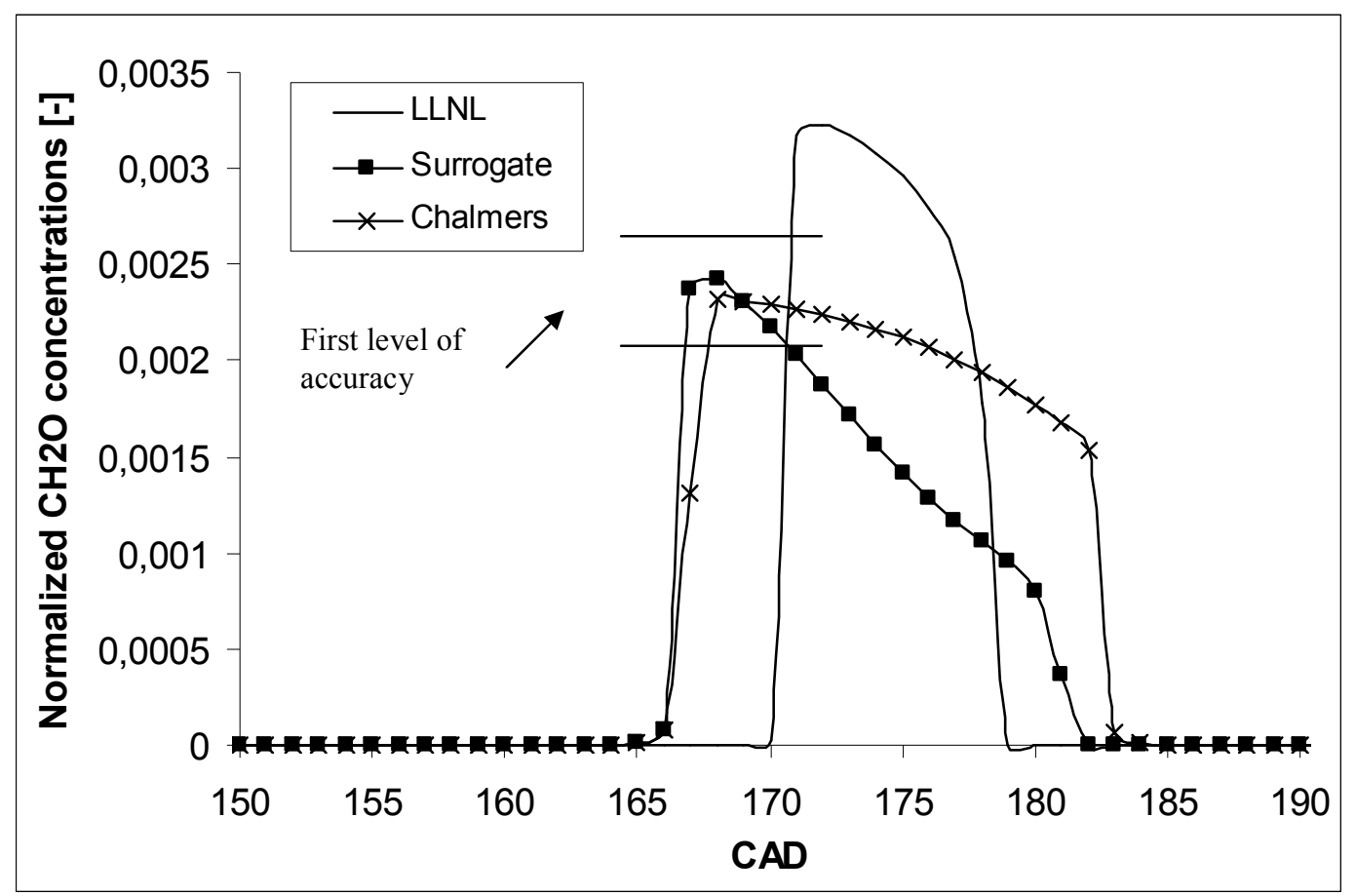

Figure 4: $\mathrm{CH}_{2} \mathrm{O}$ concentrations calculated with different mechanisms at compression ratio of 10, equivalence ratio of 0.4 and an initial temperature of $343 \mathrm{~K}$, with $n$-heptane as the fuel 


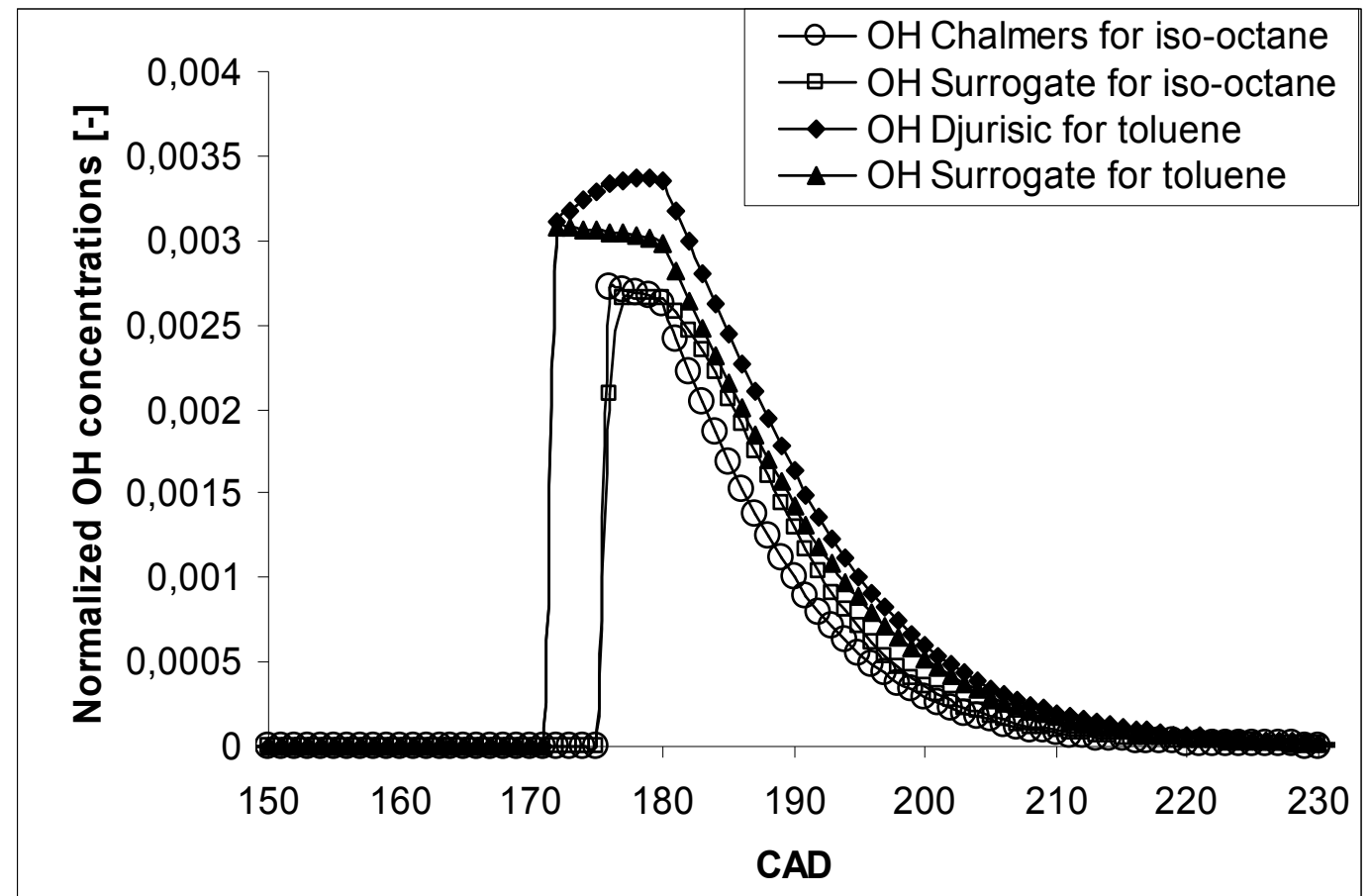

Figure 5: OH concentrations calculated by different mechanisms for iso-octane at compression ratio of 15 , equivalence ratio of 0.6 and an initial temperature of $365 \mathrm{~K}$ and for toluene at compression ratio of 16, equivalence ratio of 0.5 and an initial temperature of 500 $K$, with toluene as the fuel 


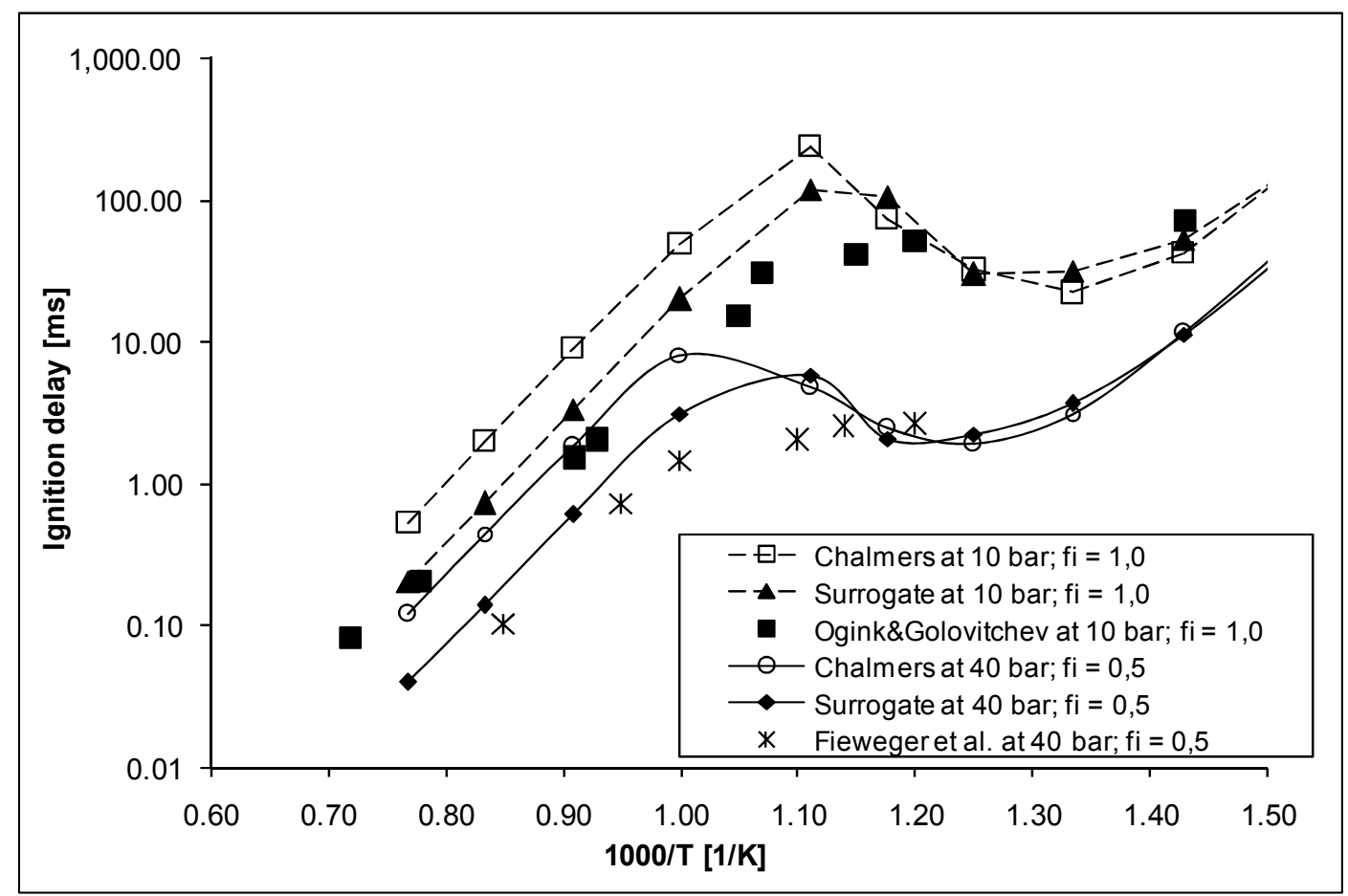

Figure 6: Comparison of the surrogate mechanism, the Chalmers mechanism and experimental data for a stoichiometric iso-octane/air mixture [7] (left y-axis), varying the initial temperature in a shock tube at a pressure of 10 bar and for an equivalence ratio $(=f i)$ of 0.5 [35] (right y-axis), varying the initial temperature in a shock tube at a pressure of 40 bar 


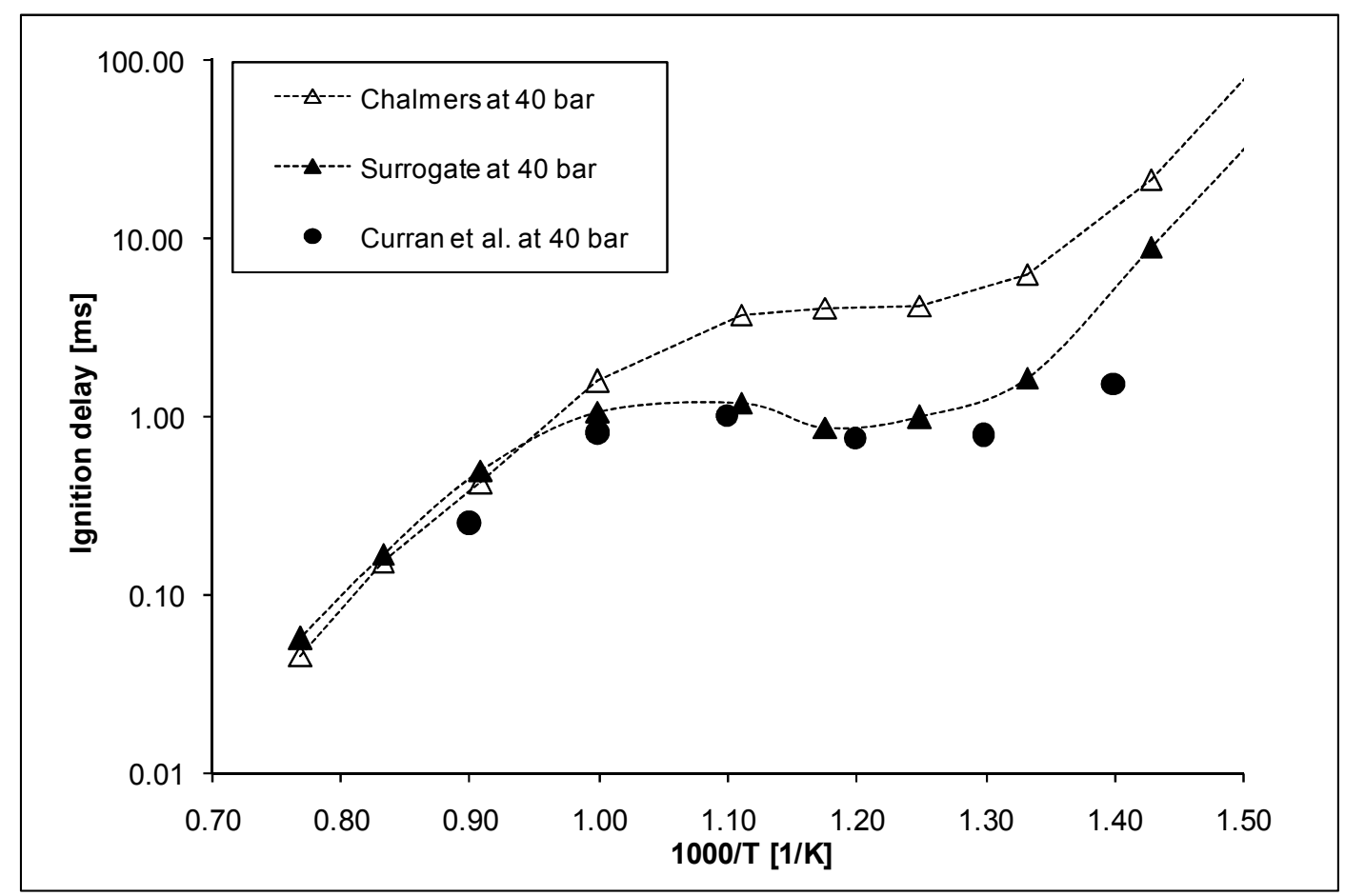

Figure 7: Comparison of the surrogate mechanism, the Chalmers mechanisms (n-heptane + iso-octane) and experimental data from [35], varying the initial temperature in a shock tube at a pressure of 40 bar with a stoichiometric PRF60/air mixture 


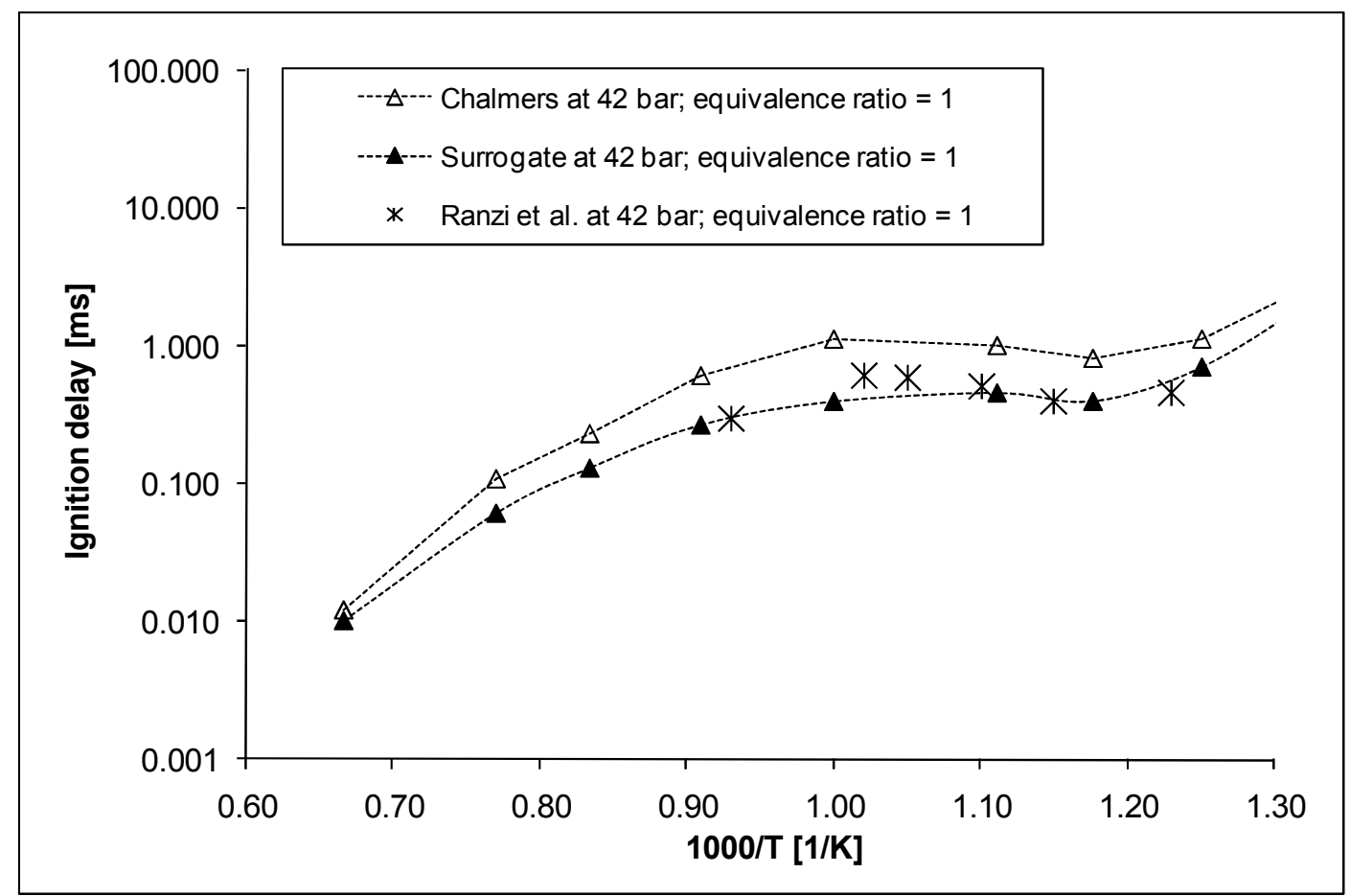

Figure 8: Comparison of the surrogate mechanism and the Chalmers mechanism and experimental data [26], varying the initial temperature in a shock tube at a pressure of 30 bar for a stoichiometric n-heptane/air mixture 


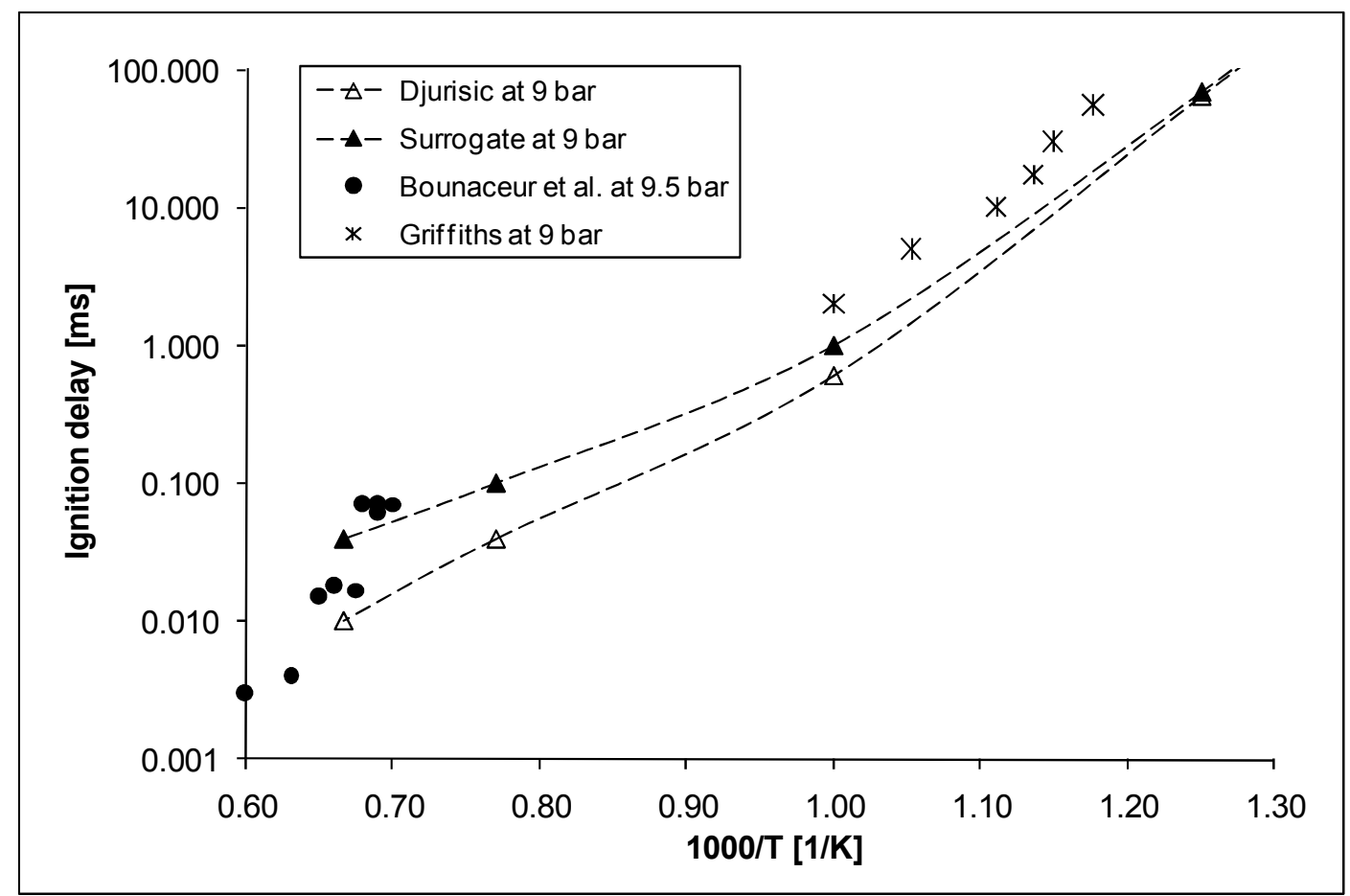

Figure 9: Comparison of the surrogate mechanism and the Djurisic mechanism and experimental data (for 9 bar in a rapid compression machine [37] and for 9.5 bar in a shock tube [38]), varying the initial temperature in a constant volume reactor at a pressure of 9 bar for a stoichiometric toluene/air mixture 


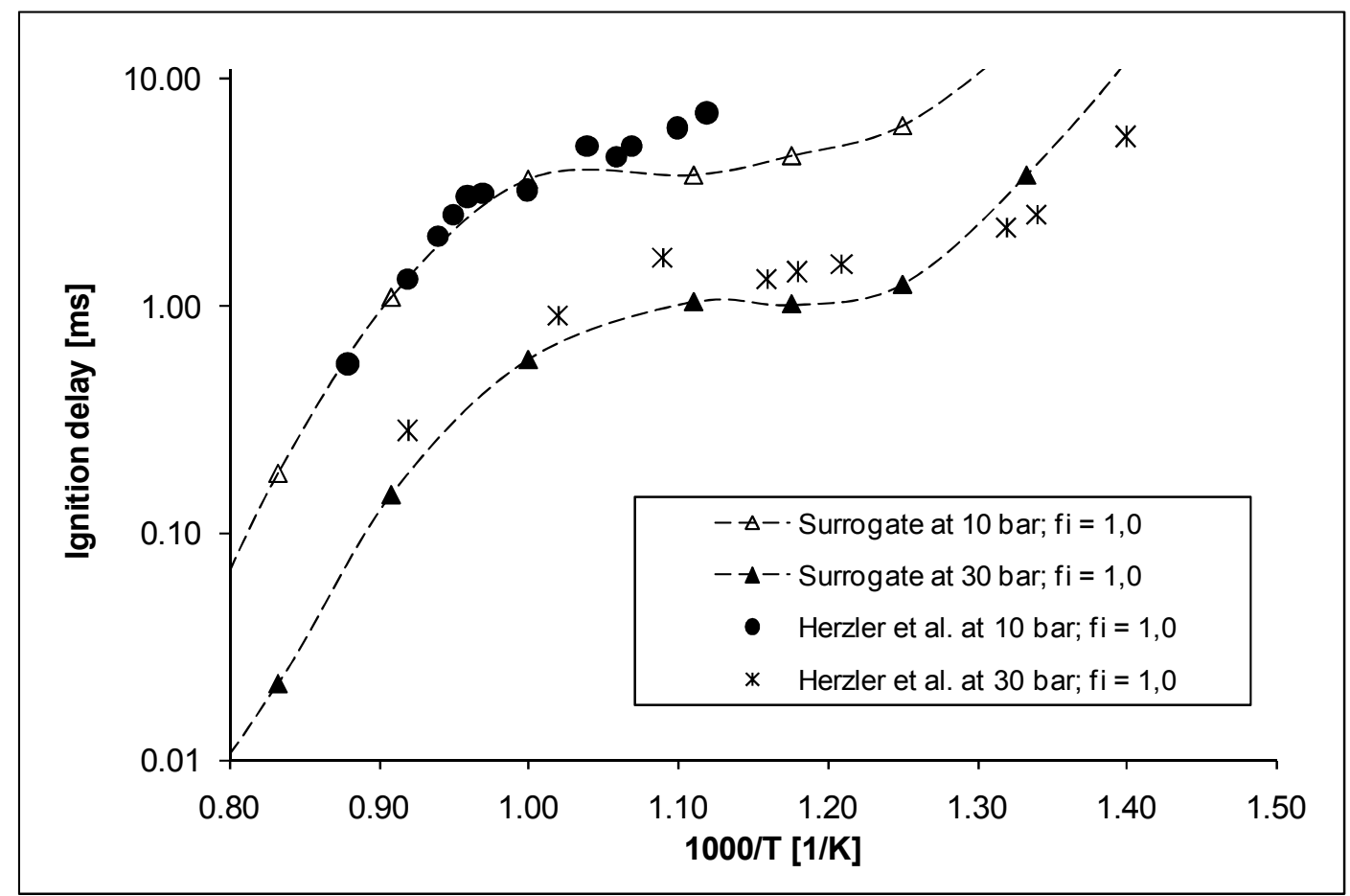

Figure 10: Comparison of the surrogate mechanism and experimental data [39], varying the initial temperature in a shock tube at pressures of 10 and 30 bar with 35 vol\% n-heptane and 65 vol\% toluene at stiochiometric conditions 


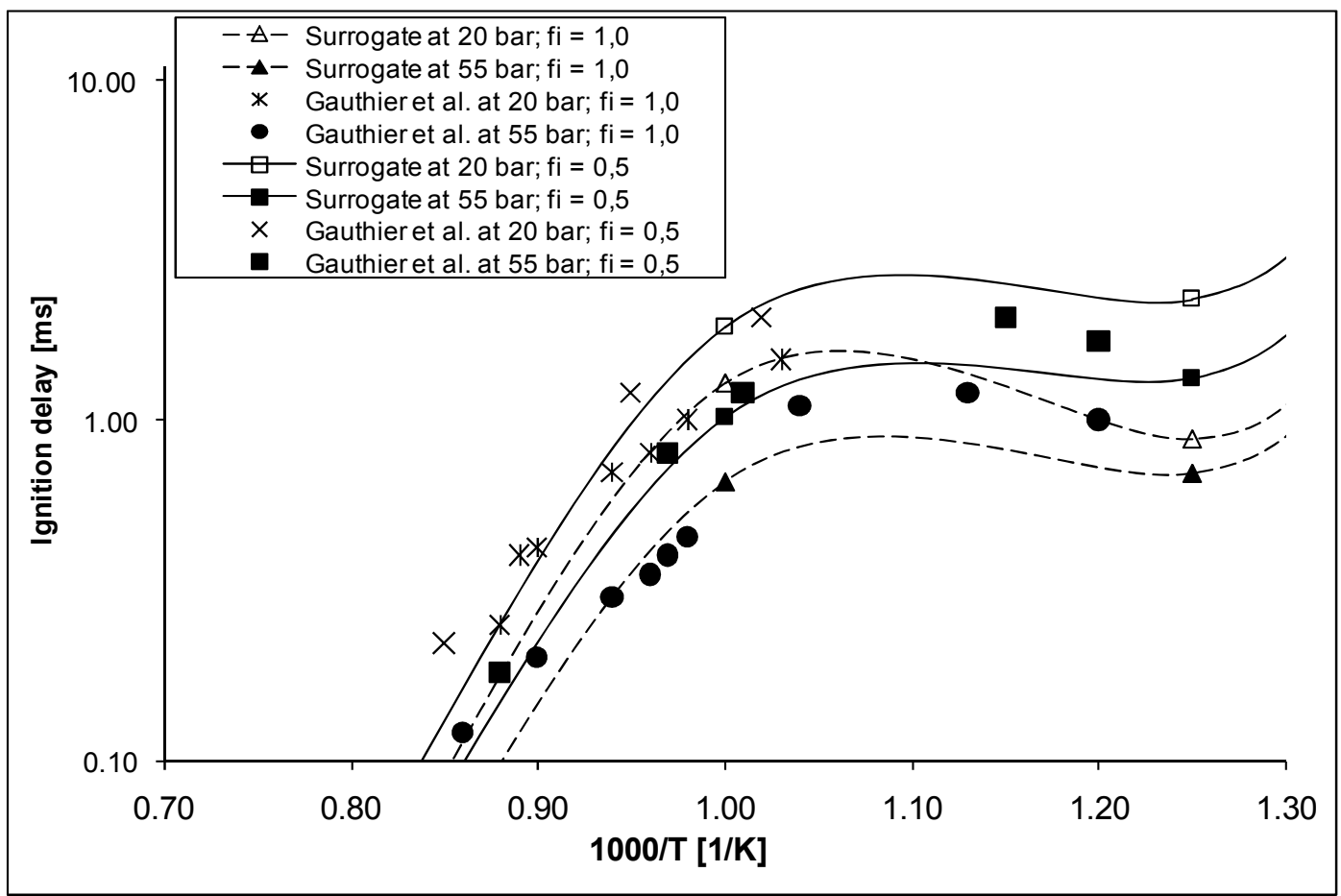

Figure 11: Comparison of the surrogate mechanism and the Djurisic mechanism and experimental data [40] for equivalence ratios (= fi) of 1.0 (left y-axis) and 0.5 (right y-axis), varying the initial temperature in a shock tube at a pressure of 20 and 55 bar with a gasoline surrogate as the fuel composed out of 17 vol\% n-heptane, 63 vol\% iso-octane and 20 vol\% toluene 


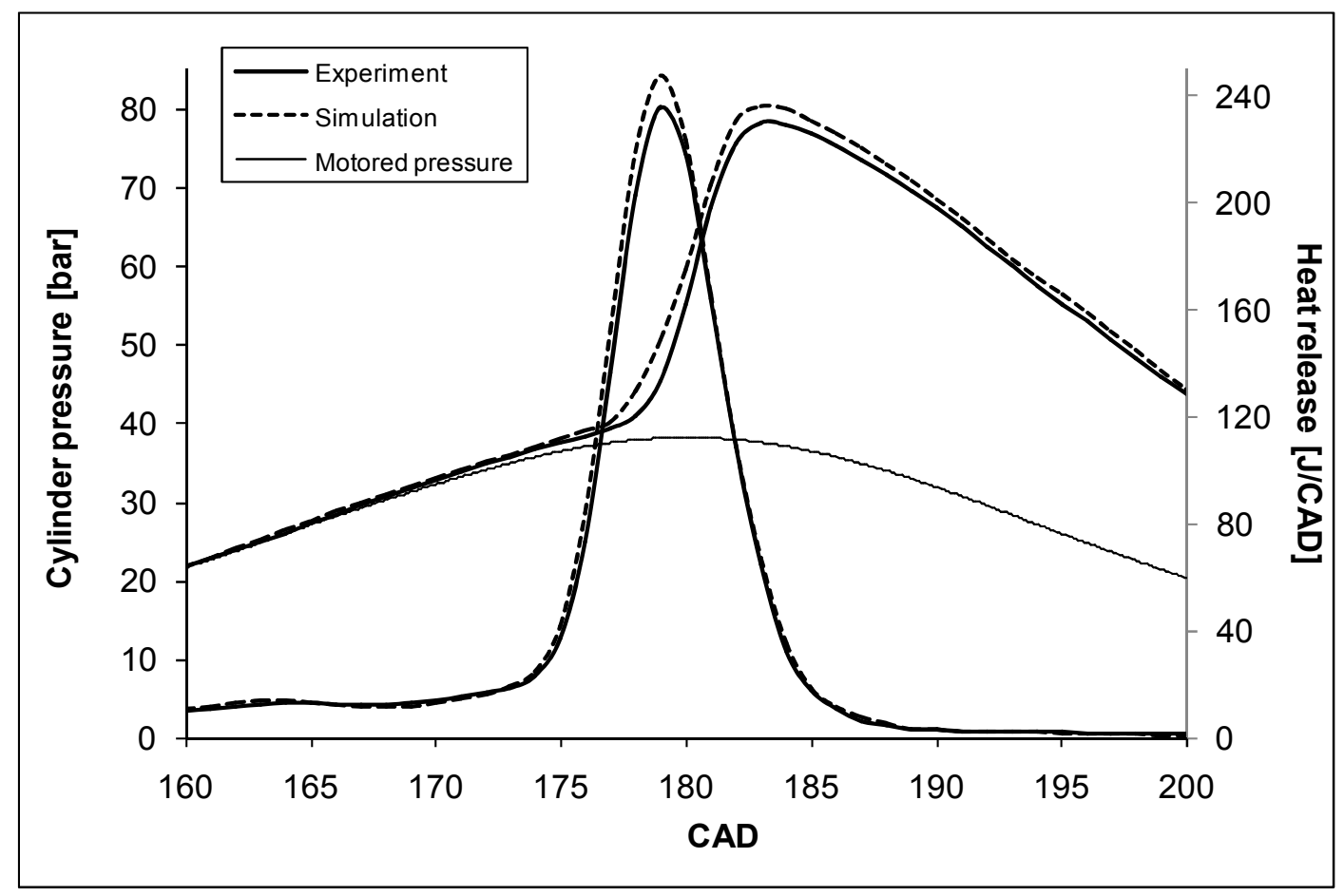

Figure 12: Comparison of the experimental and simulated pressure and heat release profiles using the gasoline surrogate at an inlet temperature of $70^{\circ} \mathrm{C}$, a compression ratio of 13.5 and an equivalence ratio of 0.46 


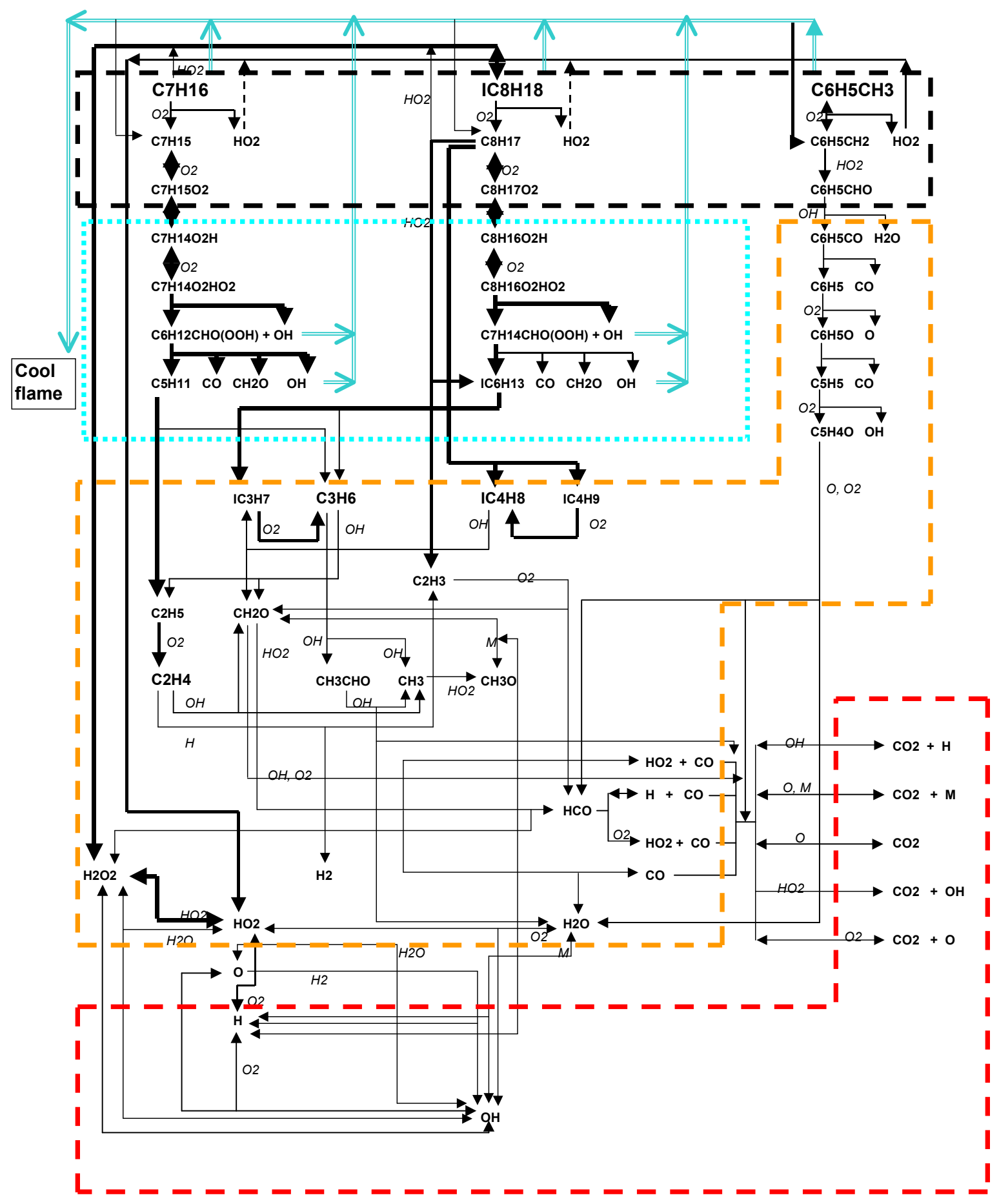

Figure 13: The global reaction scheme for the surrogate mechanism at the moment of the cool flame for a ternary gasoline surrogate composed out of 17 vol\% n-heptane, 63 vol\% isooctane and 20 vol\% toluene 


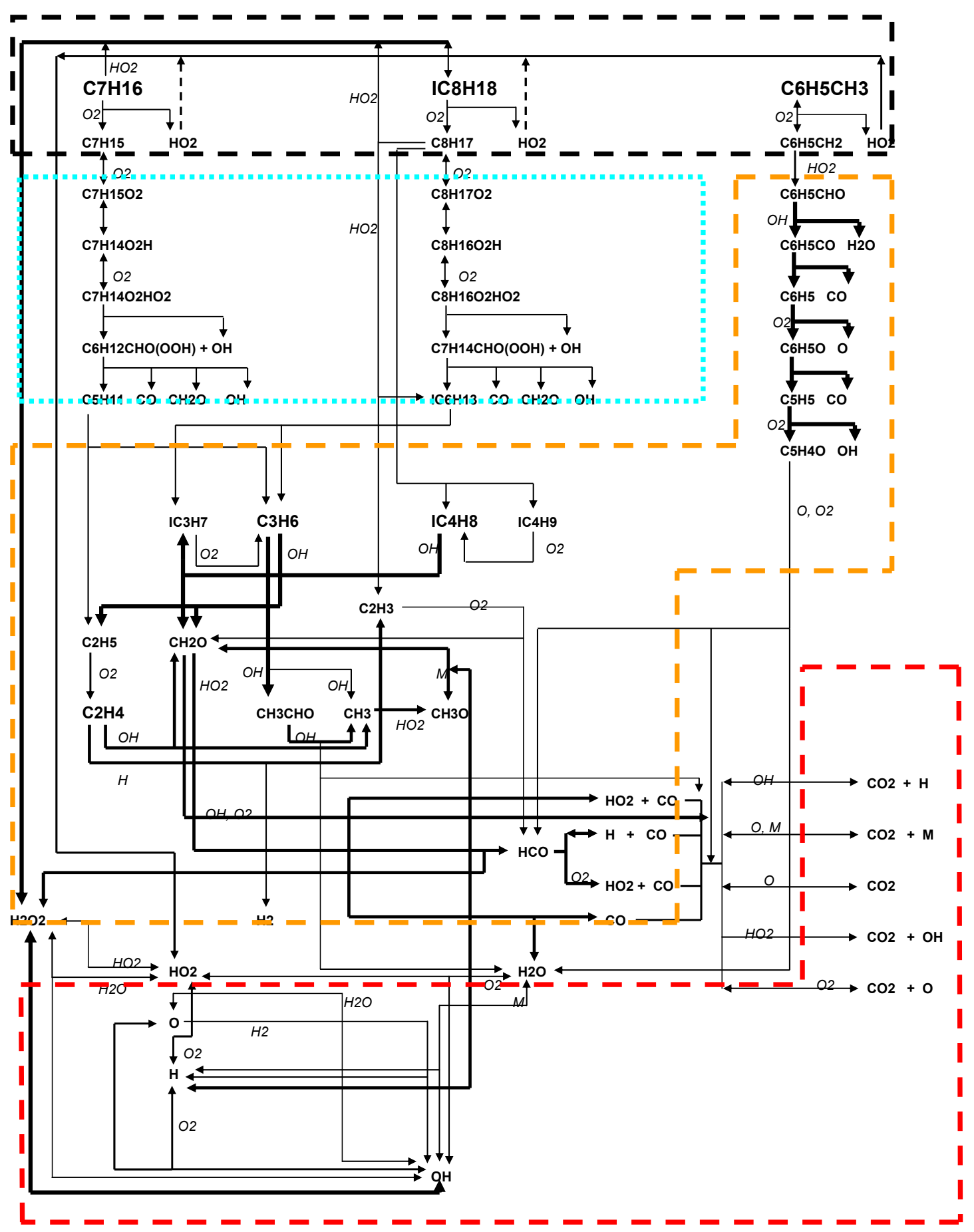

Figure 14: The global reaction scheme for the gasoline surrogate mechanism during the NTC region for a ternary gasoline surrogate composed out of 17 vol\% n-heptane, 63 vol\% isooctane and 20 vol\% toluene 


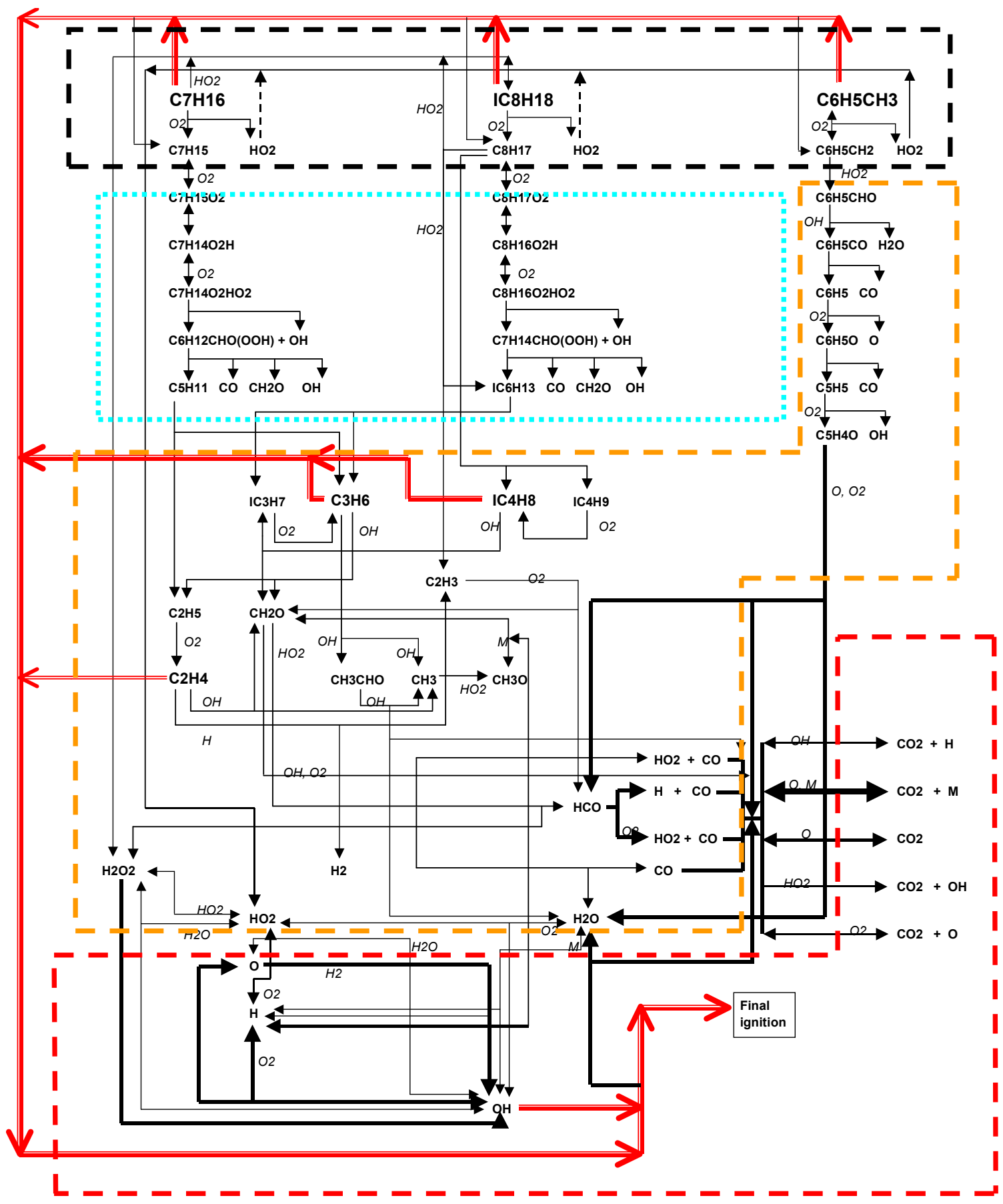

Figure 15: The global reaction scheme for the gasoline surrogate mechanism at the moment of the final ignition for a ternary gasoline surrogate composed out of 17 vol\% n-heptane, 63 vol\% iso-octane and 20 vol\% toluene 